\title{
Impact Assessment: Diffusion and Integration
}

\author{
Jonathan Baert Wiener and Daniel Lima Ribeiro \\ Duke Law School \\ DRAFT - 19 August 2014 \\ Please do not quote or cite without permission.
}

Legal tools for evaluating the environmental impacts of government actions environmental impact assessment (EIA) - were initially adopted starting around 1970. EIA has now spread globally to the national legal systems of more than one hundred countries (Sadler 1996; Craik 2008; Sand 2011). EIA is also promoted in international law (the 1992 Rio Declaration, Principle 17; the 1991 Espoo Convention on EIA in a Transboundary Context and its 2003 Protocol on Strategic Environmental Assessment; and numerous international agreements on specific topics). EIA has become a global standard for good government decision making.

Legal tools for evaluating the impacts (benefits and costs) of government regulation -- regulatory impact assessment (RIA) -- were also initially developed in the 1970s. RIA has likewise been spreading among national legal systems around the world (OECD 2009a; Cordova-Novion and Jacobzone 2011; De Francesco 2012, 2013; Quah and Toh 2012; Livermore and Revesz 2013; Wiener 2013). The idea of comparing the benefits and costs of important choices is not new (dating back at least to Franklin 1772). What is new is the spread of regulation to oversee market actors (Levi-Faur 2005; Simmons et al. 2008), and the accompanying spread of RIA systems to oversee such regulation (Radaelli and De Francesco 2008). This process of diffusion may now be maturing: RIA is now supported by a robust bipartisan consensus among all US Presidents since the 1970s, a ripening transatlantic consensus between the US and the EU since about 2001, an emerging consensus among most or all OECD member states, and a nascent global consensus. The OECD as an institution has played a significant role in promoting the adoption of RIA by its own member states and by many other governments as well (De Francesco 2012, 2013).

Meanwhile, in addition to EIA and RIA, various countries also employ other types of impact assessment. These include IAs on such types of impacts as health, energy supply, small business, takings of property rights (expropriation), federalism, trade, privacy, equality, environmental justice, gender, children, indigenous communities, and others (e.g. Lubbers 2012). Thus at the same time that IA has been increasingly adopted around the world, and increasingly applied to many topics, it has also become fragmented. IA systems addressed to different impact topics may employ different analytic approaches; and different institutions (e.g. executive, judicial, legislative, independent) in different countries may conduct and review IAs on different topic areas. One may hope that IA systems are expanding to cover all important topics in every country, thereby ameliorating the pervasive problem of disregard of important impacts on neglected groups (Stewart 2014; Wiener and Graham 1995: 230-242), inviting full public input from all affected groups, and improving policy decisions. But the evolution of multiple fragmented IA systems targeted at particular topics, using varied analytic 
approaches, and in different institutions, may also yield gaps (inadequate IA - countries or institutions lacking IA for some types of topics or decisions), overlaps (duplicative or excessive IA - with attendant costs such as delay - relative to its benefits in improving decisions), and conflicts (frictions among analytic approaches or institutions). Further, even if each country adopted a comprehensive system of IA that overcame such fragmentation internally, the diffusion of IA across countries itself poses a geographic divide, if national IA systems focus only on domestic impacts.

Among the frictions exhibited in the diffusion of IA systems is an apparent conflict between the two leading types. EIA and RIA might seem at odds: EIA is generally espoused by those seeking to shield the environment from harm, while RIA is frequently espoused by those concerned about the costs of regulation (often regulation seeking to protect the environment). Each side worries that the other type of IA is imposing delays: that EIA delays needed projects, or that RIA delays needed regulations. Yet these tools can also be seen to share a core feature: the use of information and analysis to improve decisions about the future. Their diffusion demonstrates the growing demand around the world for policy foresight (Wiener 2013). Moreover, during this process of diffusion, countries have expanded the scope of both EIA and RIA to encompass a broadening array of social impacts, including environmental, economic and social impacts (Kirkpatrick and Parker 2007). Meanwhile, though, EIA and RIA have typically been conducted and reviewed through different institutions.

While the diffusion of IA promises to extend its benefits to more countries around the world, the fragmented and variegated evolution of IA suggests the opportunity for reform. Diffusion has now set the stage for integration: by revealing the fragmentation within and across countries, and offering varied experience from which we can learn, the diffusion of IA is provoking interest in the potential consolidation of differing IA systems into one comprehensive approach to IA - or at least in a careful examination of the effects of fragmentation on the effectiveness, ancillary impacts, and implementation of IA systems. If carefully monitored and evaluated, this experience with observed variation (and new experimentation) can offer evidence that informs learning and successful improvement - a kind of IA of IA systems, akin to related efforts to promote evidence-based impact assessment in other fields such as medicine, social policy, and philanthropy-. The accumulating evidence over several decades on the diffusion of RIA, EIA and other IA systems around the world offers a renewed opportunity to assess whether and how these IA systems should be integrated into a single broader impact assessment system (Porter and Rossini, 1983) and thereby better contribute to their shared goal of policy foresight.

As societies and their governments seek tools to help foresee and evaluate the future impacts of their current choices, successful policy foresight can benefit from learning from hindsight - from retrospective studies of the accuracy and impact of RIA and EIA (and other IA systems) on past decisions, both to revise current policies and also to improve the accuracy of IA systems in the future. This chapter discusses the ongoing diffusion of IA, and the pros and cons of combining the array of existing IA systems into a new and better system of Integrated Impact Assessment (IIA) (both prospective and retrospective) encompassing the full portfolio of important impacts.

\section{The Demand for Impact Assessment and Policy Foresight}


Wiener \& Ribeiro, Impact Assessment: Diffusion and Integration (DRAFT not for quotation - August 2014)

page 3

The several types of IA reflect social demands for forecasts of the consequences of important choices, such as major projects and policies. Where governments undertake large projects or propose major policies, potentially adversely affected constituencies may demand IA to identify and reduce the harms they may suffer. Or, decision makers anticipating accountability to such constituencies may demand IA in order to identify potential impacts, compare alternative options, reduce the costs, and increase the benefits. In a principal-agent dynamic, a legislature delegating authority over a complex and difficult topic to an agency may impose an IA requirement on the agency in order to limit the agency's potential to cause undesired impacts or inform the principal of those impacts (Radaelli 2010). Impact assessments may thereby facilitate transparency, accountability, and substantive improvement of major decisions.

EIA and RIA are mechanisms of institutional oversight; they are also tools of foresight (Wiener 2013). EIA and RIA may be seen as antagonists, championed by rival constituencies (environmentalists favoring EIA, versus industry favoring RIA, and each worrying that the other type of IA will delay needed actions). In principle, this antagonism is unnecessary, because each can be - and has been - applied to a wider array of impacts, a wider array of actions, and a wider array of actors (Kirkpatrick and Parker 2007). RIA can also be used not only to constrain regulation where its costs are high, but also to promote more stringent regulation where its net benefits are high (Graham 2007; Revesz and Livermore 2008, 2014). EIA can be used not only to ensure that nonenvironmental agencies pay attention to the environmental impacts they might otherwise disregard, but also to ensure that all agencies (including environmental agencies) take a holistic view of the important environmental impacts of their actions (Cosco 1998). The evolution of EIA into related approaches such as "sustainability assessment" and "strategic environmental assessment" have broadened their ambit to include social and economic as well as environmental impacts (the "triple bottom line" of sustainability). Thus, EIA and RIA are better understood as complementary components of the deeper need for foresight. Both EIA and RIA are efforts to forecast the future consequences of current choices (and, when applied retrospectively, both to assess the actual consequences of past choices, and to assess the accuracy of the earlier prospective IA).

Humans have a distinctive capacity to envision future scenarios, which Gilbert and Wilson (2007) dub "prospection." But the future scenarios that our brains employ in ordinary life tend to be collages of our own memories, rooted in what is mentally available (Gilbert and Wilson 2007; Schachter, Addis, and Buckner 2008). This mental mechanism helps explain the "availiability heuristic" in which public perceptions are galvanized by salient recent events that motivate response actions without thinking through the full consequences (Sunstein and Kuran 1999). Moreover, individuals and institutions, such as business firms and government agencies, face incentives to neglect the harms they impose on others (externalities). Better foresight requires structured methods to overcome these limitations and ensure that all important consequences are considered. Franklin (1772) espoused an early form of impact assessment as a tool to help overcome cognitive errors, assembling all the key reasons "pro and con" to view "the whole" and ensure that they are "present to the Mind at the same time" so that thereby one can "judge better" and avoid "a rash Step." Along these lines, Sunstein (2000) advocated impact assessment as a cognitive decision aid toward optimal 
Wiener \& Ribeiro, Impact Assessment: Diffusion and Integration (DRAFT not for quotation - August 2014)

regulation, Rachlinksi and Farina (2002: 596-603) advocated external expert review as one way to remedy regulatory agencies' cognitive errors, and Seidenfeld (2002) made a similar case for judicial review. Wiener and Graham (1995) argued that neglect of ancillary impacts arises from both cognitive and institutional limitations, and advocated a more holistic framework for impact assessment to ensure that decision makers consider these ancillary impacts. Wiener $(2002,2006)$ urged "warm analysis" to ensure consideration of the "full portfolio" of important consequences, including ancillary impacts (both harms and benefits), as superior to more precisely quantifying a more narrow subset of the consequences. Impact assessment needs to embrace this full scope.

The ongoing diffusion of more narrow impact assessment tools may be spreading the concept and practice of IA, but also conflicting with the need for comprehensive appraisal of the full scope of impacts. The demand for policy foresight appears to grow with prosperity and with longevity. Rising incomes foster rising demand for amenities such as environmental quality and risk protection, which necessitate attention to longerterm impacts. And economic growth brings new technologies that reduce some risks but may also create new risks, triggering public demand for assessment. Prosperity also enhances the scientific methods used to detect more subtle and latent risks, reducing the costs of foresight. (Along these lines, De Francesco 2013: 76 finds that earlier adoption of IA is generally correlated with higher per capita GDP.) Meanwhile, greater longevity - resulting from a combination of prosperity, nutrition, public health measures, public policies to regulate risks, and other factors - may also increase demand for foresight. Even though greater longevity itself reflects decreasing risks, longer life spans may also lead people to care more about risks that may arise farther into the future. And, in a decreasing-risk (safer) world, those risks that do occur may be seen as more egregious and scandalous, spurring greater demand for protective measures (Godard et al. 2002: 29). In turn, because regulations to reduce these risks can (like medical therapies) impose their own side effects (Wiener 1998, 2002), demand rises for RIA - a mechanism for foresight about policy impacts, including costs, target benefits, and ancillary impacts.

As a society becomes even safer through the joint effects of prosperity, precaution, and better regulation, it may become concerned about even lower-probability extreme catastrophic risks that would earlier have escaped attention but that are now worth preventing (Posner 2004; Sunstein 2007). Prosperity enhances scientific capabilities to detect remote risks, and longer life spans mean that extreme risks become more plausible within one's own lifetime and the lifetime of one's descendants. Still, these extreme risks may be neglected because of cognitive limitations - if they are so rare that no salient incident triggers the "availability" heuristic (Weber 2006), or so large that the public becomes numb to their magnitude (Slovic 2007). These are "tragedies of the uncommons" which deserve expert attention, both to choose priorities among remote scenarios and to avoid the potential ancillary impacts of prevention measures (Wiener 2005, 2011). Thus, structured impact assessment is needed to ensure attention to these remote catastrophic impacts and the impacts of policy measures to prevent them.

EIA and RIA offer complementary tools to inform these decisions. The international diffusion of these tools, spurred by the factors noted above, means that more countries are equipping their governments to think things through. The observed variation across countries in the design of EIA and RIA systems offers researchers an opportunity to compare design features and learn how to improve these tools. Diffusion 
can go awry if policymakers are not well informed about these policy measures and their impacts (Elkins and Simmons 2005). To ensure careful study and learning, we should consciously construct a global policy laboratory that compares outcomes across instrument designs (Greenstone 2009; Wiener 2011). To do so, we need some hindsight - retrospective evaluation of choices, including their full portfolio impacts - in order to see whether the ex ante impact assessments (EIA and RIA) were accurate forecasts of future impacts, and how to improve their accuracy in subsequent attempts at foresight (Coglianese and Bennear 2005).

The demand for impact assessment also reflects public desire to participate in decisions (see the chapter by Stijn Smismans in this volume). Particularly in jurisdictions lacking notice and comment rulemaking, IA can play an important democratic role as a process and platform for public input and social learning. Even in countries with notice and comment rulemaking (which may suffer its own shortcomings in public participation, see the chapter by Wendy Wagner in this volume), IA can be important in both eliciting and informing public input on the impacts to be considered; this has been a key purpose of EIA and RIA in the US, and of stakeholder consultation through Better Regulation in the EU. IA can enable input in the decision process from affected groups, especially when a group's interests were an "omitted voice" in prior political (e.g. legislative) or administrative stages of policy making (Wiener and Graham 1995; Croley 2008). Sunstein (2013b) emphasizes the role of RIA and its oversight as an "information aggregator," ensuring that all viewpoints are considered in making important regulatory decisions. IA and its public participation mechanisms can foster the principle of open government (OECD 2012a), combining elements of participatory and deliberative democracy (Chambers 2003), and indicating a shift in political dynamics from elite government decision making to more inclusive networks of governance (Rozema et al. 2012). Advocates of this participatory function of IA argue that it can also improve substantive outcomes, by drawing on local knowledge of impacts, their causes and significance (Becker et al. 2003; Newig and Fritsch 2009); eliciting the knowledge, values and creativity of the public for identification and evaluation of alternatives, scope, and outcomes (Surowiecki 2004; Rozema et al. 2012; Sunstein 2013a); and improving future compliance (Macnaghten and Jacobs 1997).

Nonetheless, IA has its skeptics. As noted above, a chief concern is delay. Critics fear that adding analytic requirements and review may yield "ossification" or "paralysis by analysis" (Mashaw and Harfst 1990; McGarity 1992; Shapiro and Morrall 2013). The time needed for drafting and review of EIAs can be several years, including many months for judicial review, appeals, and revisions. Executive oversight review of RIA in the US is supposed to take no more than 90 days, and has typically averaged about 50 days, but in early 2013 the average rose to more than 140 days (Copeland 2013). At times the critique of delay in IA appears to be partial and outcome-driven, as when environmentalists criticize delay in RIA while favoring delay in EIA, or businesses criticize delay in EIA while favoring delay in RIA, or critics of delay in RIA as applied to one type of rule (say, environmental) favor delay in RIA as applied to another type (say, counterterrorism). If the costs of IA - whether RIA or EIA or other types - are high, that may hinder needed decision making, and agencies or ministries may seek to circumvent costly IA and oversight requirements (Mendelson and Wiener 2014). 
Wiener \& Ribeiro, Impact Assessment: Diffusion and Integration (DRAFT not for quotation - August 2014)

page 6

A second concern is that IA may be biased by giving greater weight to some kinds of impacts (e.g. costs to industry in RIA) than to others (e.g. health and environmental benefits), or serving as a conduit for some political interests to hold sway over others. Yet retrospective studies find that this concern is overstated and that RIA and CBA can not only restrain unwise regulation but can also promote wise protective regulation (Croley 2003; Croley 2008; Graham 2007; Revesz and Livermore 2014).

A third objection is that the decision making advantages of IA are undermined by undeclared assumptions, value judgments, and uncertainties (Ackerman and Heinzerling 2004; Kysar 2010). These objections tend to be raised by critics of RIA, but they may apply to EIA as well (whose critics may not only dislike its project delays but also argue that it privileges parochial environmental concerns over other public interests such as economic growth or national security).

These criticisms of IA must be evaluated in comparison to the alternatives to IA. Decisions made without impact assessment, that is, without assessment of policy or project alternatives, and without foresight regarding their consequences - whether RIA or EIA - might be faster, but would likely be even more vulnerable to the biases, distortions and undesired outcomes that sound IA can overcome (Stiglitz 1997; Stern and Wiener 2008). These criticisms of IA may thus favor improvement, and not abandonment, of IA. Much literature has been devoted to improving IA, such as by engaging analysis earlier to reduce delay, tailoring the extent of analysis to the stakes of the decision ("proportionate analysis"), improving quantification of important values, encompassing distributional equity and broader measures of social well-being, and ensuring attention to important ancillary impacts (e.g. Adler 2012; Revesz and Livermore 2008; Graham 2007; Wiener 2006; Dolan et al. 2001).

\section{Institutions for Impact Assessment}

The legal rules and oversight systems of impact assessment differ across types of impact assessment and across countries. Impact assessments are typically reviewed by some oversight body in order to ensure that they are sufficiently thorough and are properly employed in decision making (OECD 2009a). The oversight function may be located in the judiciary (judicial review of legislative or administrative action), the executive (center-of-government regulatory review, typically in the presidency or head of government; or in a relevant agency, or a multiagency council), the legislature (an expert body assisting the legislature, or legislative review of administrative action), or an independent entity (such as a neutral review board, auditor, or ombudsman).

\section{A. EIA}

In the United States, the National Environmental Policy Act (NEPA) of 1969 required an environmental impact statement for all major federal actions significantly affecting the environment (42 U.S.C. \$4332). Guidelines on implementing NEPA have been issued by the White House Council on Environmental Quality (CEQ) (40 CFR 1500-1508). Major federal actions triggering NEPA's EIA requirements are typically large projects or programs financed or directed by federal agencies, including construction projects, forest and land use decisions, energy extraction and generation, scientific research experiments, spaceship launches, and others. The EIA requirements 
Wiener \& Ribeiro, Impact Assessment: Diffusion and Integration (DRAFT not for quotation - August 2014)

page 7

may also be triggered by agencies' proposals for legislation (though these EIAs have been rare), and by agencies' administrative actions (such as permitting, licensing and rulemaking - although several kinds of agency administrative action are exempted from NEPA's EIA requirements, including certain actions exempted under statutes such as the Clean Air Act, the Clean Water Act, and others; various "categorical exclusions" under CEQ guidelines; and other actions exempted by judicial doctrines such as "functional equivalence"). Each year, US federal agencies produce many thousands of EIAs pursuant to NEPA. (In addition, since the federal enactment of NEPA in 1969, almost twenty US member states have enacted their own state-level EIA laws, and several other states have developed administrative EIA programs.)

The American federal EIA process is subject to executive oversight, involving CEQ, the Environmental Protection Agency (EPA), and broader interagency review. In 1970, EPA was given a special role by Section 309 of the Clean Air Act in supervising federal agency compliance with the requirements of NEPA (40 U.S.C. § 7609). Every draft and final EIA must be filed with EPA for review. Once completed, the EPA is required to publish its review of the EIA. In the case it considers the EIA content "unsatisfactory from the standpoint of public health or welfare or environmental quality," it must refer the case to the CEQ for resolution. Other agencies may make similar reviews and also refer the case to the CEQ based on their judgments of the acceptability of anticipated impacts. If CEQ sides with the referring agency and the lead agency refuses to implement the necessary changes, CEQ may then publish a recommendation and refer the case to the President for action (40 CFR 1504).

Historically, US federal courts have been significantly more active than CEQ in hearing challenges to agency compliance with EIA requirements. NEPA was initially interpreted by courts to require a benefit-cost analysis, in which previously neglected environmental costs were to be assessed and weighed against the (non-environmental) project benefits as part of the decision whether to go ahead with a proposed federal action or instead choose a superior alternative (Calvert Cliffs Coordinating Committee v. AEC, 449 F.2d 1109 (D.C. Cir. 1971)). But later Supreme Court decisions held that NEPA's EIA requirements are purely procedural, not substantive, and only require an agency to stop and think through the environmental impacts before acting - the agency is not required by NEPA to balance those environmental impacts against the project's benefits, nor to choose the alternative that mitigates, minimizes or optimizes those net impacts (Strycker's Bay Neighborhood Council, Inc. v. Karlen, 444 U. S. 223 (1980); Robertson v. Methow Valley Citizens Council, 490 U.S. 332 (1989)). Still, litigants can delay a project by persuading a court that the EIA has been inadequate, for example if it has omitted important impacts, or needs to be supplemented to account for new information. Such delays due to NEPA litigation have given environmental advocates significant leverage to persuade agencies to abandon or redesign projects.

In Europe, the Council of the European Communities issued its Directive on EIA in 1985 (85/337/EEC), which it has amended several times, including in Directives 97/11, 2001/42, 2009/31, 2011/92/EU, and 2012/0297 (October 2012). These EU Directives on EIA are intended to promote effective and consistent application of EIA among the EU member states. France adopted its own EIA system in 1976, the Netherlands in 1978, and Croatia in 1984. But most EU member states adopted their EIA systems after the EU directives began in 1985 (De Francesco 2013: 75). Under Directive 
Wiener \& Ribeiro, Impact Assessment: Diffusion and Integration (DRAFT not for quotation - August 2014)

page 8

2011/92/EU, EIA in the EU applies to individual projects, including a list (Annex I) of specific types of projects for which EIA is obligatory, and a set of factors that member states may apply in "screening" to determine whether other projects (not on the Annex I list) also warrant EIA. In addition, Directive 2001/42/EC calls for "Strategic Environmental Assessment" (SEA) of public programs and plans. SEA of policies, plans, and programs is also the subject of the Protocol on Strategic Environmental Assessment that supplements the UNECE Espoo Convention. And the Aarhus Convention, signed by the EU and approved by Decision 2005/370, also creates enforceable rights to environmental information. As in the US system, judicial review is the main institution to enforce European EIA requirements; European citizens can challenge final decisions based on EIAs and SEAs in the EU courts and in member state courts.

\section{B. RIA}

Unlike EIAs reviewed primarily in the courts, RIAs tend to be reviewed by a specialized "regulatory oversight body" (ROB), which typically means a centralized government unit in the executive hierarchy that supervises regulatory action by agencies (Lindseth, Aman, and Raul 2008; Wiener and Alemanno 2010; Cordova-Novion and Jacobzone 2011; Wiener 2013). ROBs provide both expertise (through professional staff and methodologies such as cost-benefit and cost-effectiveness analysis) and political accountability (such as to the president or prime minister). These criteria may be mutually reinforcing, but at times may pose tensions (Shapiro 2006).

ROBs may have a variety of functions and powers. An ROB may comment on (and assist in improving) the quality of an agency's RIA; collect the comments of other agencies and the public on an agency's proposed action and seek to improve it; constrain an agency's proposed action when the ROB deems the quality of an RIA to be inadequate, or when the RIA shows that the benefits of the agency's proposed action do not justify the costs; call on agencies to review the stock of existing policies for their benefits and costs; prompt agency action when the ROB identifies a socially promising policy that agencies are not yet promulgating; and foster transparency in the reporting of policy impacts. (The ROB itself may be transparent about its own contacts and activities, or it may lack transparency; and it may face criticism for perceived bias toward particular viewpoints or constituencies.)

The functions and powers of ROBs may differ across polities, partly as a policy choice, and partly because ROBs may be located in different branches or units of different constitutional structures accorded different roles and powers, such as parliamentary versus presidential systems (Wiener and Alemanno 2010). The ROB's authority to guide regulatory decision-making will depend on its institutional role among the branches or power centers of government.

For example, in the United States, the ROB is the Office of Information and Regulatory Affairs (OIRA), located within the Office of Management and Budget (OMB) in the Executive Office of the President. OIRA performs multiple functions, pursuant to a series of executive orders issued by every president of both political parties since the 1970s - reflecting a bipartisan consensus among US presidents in favor of centralized executive oversight of the regulatory system. OIRA is headed by a single Administrator (appointed by the President with Senate confirmation) and has a professional staff of 
Wiener \& Ribeiro, Impact Assessment: Diffusion and Integration (DRAFT not for quotation - August 2014)

page 9

career non-political appointees (about 80 in the 1980s, but down to about 40 today). President Jimmy Carter's Executive Order 12,044 of 1978, preceding OIRA, had called for agencies to accompany proposed regulations with RIAs, and for oversight to be undertaken by a multi-member Regulatory Analysis Review Group (RARG). Near the end of President Carter's term, he signed the Paperwork Reduction Act of 1980 which created OIRA. President Ronald Reagan took office in January 1981 and almost immediately issued Executive Order 12,291, assigning oversight of RIAs to OMB/OIRA, and requiring regulations to pass a cost-benefit test. President George H.W. Bush retained EO 12,291. President Bill Clinton, despite rumors that he might rescind EO 12,291 and end OIRA oversight of RIAs, instead replaced the Reagan EO with a new Executive Order 12,866 (1993), which retained OIRA oversight of RIAs and the requirement of cost-benefit analysis. EO 12,866 did introduce several changes, including requiring that benefits "justify" (rather than "outweigh") the costs; adding emphasis to qualitative impacts, distributional equity, and risk-risk tradeoffs; and increasing transparency (Kagan 2001; Wiener 2006). The Clinton EO remains in force today, retained by Presidents George W. Bush and Barack Obama. Indeed, it has been reinforced and extended by Barack Obama's Executive Orders 13,563 (on oversight in general and retrospective review of existing regulations) and 13,579 (on independent agencies) of 2011, and EOs 13,609 (on international regulatory cooperation) and 13,610 (on reducing regulatory burdens) of 2012.

Under these EOs, OIRA has the authority to "return" agency regulatory proposals that do not meet the analytic and net benefits criteria set forth in the executive order (requiring the agency to revise its RIA and/or its proposal). In addition, in the last decade, OIRA has also (although only occasionally) sent a "prompt" to agencies to pursue new regulations that promise net benefits (such as prompting FDA to add trans-fat content to food package nutrition labels) (Graham 2007; Revesz and Livermore 2008). OIRA review has historically applied to "executive" agencies (e.g. EPA, FDA, OSHA, NHTSA, etc.), and not to "independent" agencies (typically commissions such as the Securities and Exchange Commission (SEC), Commodities Futures Trading Commission (CFTC), Federal Trade Commission (FTC), Federal Communications Commission (FCC), Federal Energy Regulatory Commission (FERC), Nuclear Regulatory Commission (NRC), Consumer Product Safety Commission (CPSC), and the new Consumer Financial Protection Bureau (CFPB)). But in 2011 President Obama issued EO 13,579, encouraging the independent agencies to comply with the goals and IA process of his EO 13,563. Scholars have argued that presidential oversight should apply to both types of agencies and that the distinction between executive and independent agencies is not sharp or should be relaxed (e.g. Katzen 2011: 109-110; Datla and Revesz 2013; ACUS 2013). Legislation has been proposed in Congress to achieve this result (e.g. the Regulatory Accountability Act).

Cost-benefit analysis had been employed in the United States to assess public projects long before the creation of OIRA, including for flood control projects (at least since the Flood Control Act of 1936) and for military procurement decisions (especially in the 1960s) (Quah and Toh 2012). Following the wave of regulatory legislation and the expansion of the administrative state during the 1960s and 70s, the advent of RIA in the 1970s and OIRA review in the 1980s created a new institutional structure for regulatory oversight, maintained and reaffirmed in a bipartisan consensus across every presidential 
Wiener \& Ribeiro, Impact Assessment: Diffusion and Integration (DRAFT not for quotation - August 2014)

page 10

administration since the 1970s (Kagan 2001; Wiener and Alemanno 2010).

Internationally, the US was the first country to establish an RIA system and continues to be "the leader in RIA practices" (De Francesco 2013: 75, 132). Many of the US member states have also adopted RIA systems (Schwartz 2010) (cf. Glaeser and Sunstein 2014, urging adoption of RIA by more of the US states).

In the United States, RIAs and OIRA review operate in a presidential system with separation of powers. Statutes enacted by the Congress delegate regulatory authority to administrative agencies. Pursuant to the Presidents' Executive Orders, RIA is then employed by administrative agencies to assess their policy choices (such as rulemakings) under the authority delegated by the legislature through statutes, and these RIAs and policy choices are reviewed by OIRA. But such a system of RIA has not been applied to proposals for legislation (bills) in the legislature (Congress). Congress has its own expert body to help evaluate spending decisions (the Congressional Budget Office, $\mathrm{CBO}$ ), and there has been increasing interest - notably at OMB, CEA, and among scholars - in evidence-based evaluation of the impacts, performance, and outcomes of federal spending programs (CEA 2014; Schuck 2014). But Congress has no counterpart institution for impact assessment of new or existing regulatory decisions embodied in legislation. Congress formerly had its own Office of Technology Assessment (OTA), but OTA ceased operating in the 1990s. Occasionally members of Congress request impact assessments of major bills from relevant administrative agencies or think tanks; or request research on past laws and their implementation, from the Congressional Research Service (CRS) or the Administrative Conference of the US (ACUS) or the General Accountability Office (GAO). But a regularized system of RIA of proposed or existing legislation has not been established.

In the European Union, impact assessment was launched by the Better Regulation Initiative over 2001-2006, as part of the Lisbon Agenda to make the European economy more competitive, influenced as well by the commitment adopted at the 200 Göteborg Council to develop a tool for sustainable impact assessment (Renda 2011: 52). Following a recommendation by the Mandelkern Commission in 2001, the European Commission introduced IA in 2002 (Renda 2011: 52-55), and issued new Impact Assessment Guidelines in 2005 (later revised in 2009 and under pending revision in 2014) (Renda 2011: 56-57; Wiener 2006). The IA system in the EU encompasses environmental, economic and social impacts, and covers policies by any Directorate General (DG) or other regulatory unit on any subject matter in the Commission's annual Work Programme. Whereas RIA in the US applies to administrative agency action after the Congress has enacted legislation, in the EU, impact assessment and IAB review apply to legislative proposals, non-legislative initiatives (e.g., white papers, actions plans, expenditure programmes, negotiating guidelines for international agreements), delegated acts and implementing measures (i.e., regulations, formerly referred to as "comitology" procedure or items) with significant expected impacts (Renda et al. 2013; Melloni 2013; Alemanno and Meuwese 2013).

The EU's ROB, the Impact Assessment Board (IAB), was then launched in November 2006. The IAB, a nine-member board whose members are seconded from the Directorates General (DGs), is located within the Secretariat General in the Presidency of the European Commission and chaired by the Deputy Secretary General. Initially, its function was to comment on the quality of RIAs, but it has quickly grown to play a wider 
role (Wiener and Alemanno 2010). Although the IAB initially lacked the authority to constrain a proposed regulatory policy, in 2010 the President of the European Commission (José Manuel Barroso) required new regulatory proposals to obtain a positive opinion from the IAB before going forward (European Commission 2010b: 1112 ), thereby giving the IAB an authority more akin to OIRA's "return letter" than the IAB had previously had. The IAB also has the authority to issue "prompt" letters, at least to nudge a DG to conduct an IA. Strikingly, while the IAB returned for "resubmission" only 9 percent of the DGs' regulatory proposals in 2007 , by 2010 it was returning 42 percent (and its resubmission rate ranged between 33 and 47 percent in each year from 2008 to 2013) (European Commission 2014a, Fig. 1). In its 2010 communication on "smart regulation" (European Commission 2010c), the European Commission further strengthened its IA system, requiring that new or revised legislation should be based on a proper ex-post evaluation of the existing policy framework, which evolved into the Commission's program to evaluate "regulatory fitness" (European Commission 2014c).

The European Parliament established its own Impact Assessment Unit in 2012, as part of its new Directorate for Impact Assessment and European Added Value. Among its main functions are the preparation of new IAs on substantive amendments to legislative proposals, and the evaluation of IAs prepared by the Commission's IAB (the latter generating some friction with the IAB). Meanwhile, RIA has also been applied in several EU member states, including the UK, the Netherlands, and others. In France, the Organic Law of April 15, 2009 (Loi organique $\mathrm{n}^{\circ} 2009-403$ du 15 avril 2009 relative à l'application des articles 34-1, 39 et 44 de la Constitution) requires an impact analysis reviewed by the Conseil d'Etat before a bill can be proposed to the National Assembly.

In addition to executive oversight by a centralized ROB such as US OIRA or the EU IAB, and legislative oversight, it is also conceivable that the courts could also review RIA, at least where legislation authorizes judicial review of agency action. US courts do not review and enforce agency compliance with the RIA requirements of the Executive Order itself, because the EO is viewed as an internal management mechanism within the Executive branch and does not create any rights enforceable in court (as EO 12,866 itself provides in its section 10). But the analysis in the RIA could be used as evidence in a court challenge to a rulemaking under a relevant statute. For example, in the US, lawsuits challenging agency rulemaking may argue that the rule is "arbitrary and capricious" under the Administrative Procedure Act (APA), in which case the analysis in the RIA may offer evidence that is relevant to the court's review; or challenges may argue that the rule violates other substantive criteria in the regulatory statute (such as requirements to weigh costs and benefits, or to apply a "reasonableness" standard) for which the analysis in the RIA is useful evidence. (Recent examples of courts considering the social science evidence of policy impacts in judicial review include Discount Tobacco City \& Lottery, Inc. v. United States, 674 F.3d 509 (6th Cir. 2012) (finding sufficient evidence of policy impact), cert. denied April 22, 2013), and R.J. Reynolds Tobacco Co. v. FDA (D.C. Cir. August 24, 2012) (finding insufficient evidence of policy impact).) Some US statutes prohibit the agency from considering costs in setting standards, in which case the RIA may be - ostensibly - separate from the agency's standard-setting and from the court's review (see Revesz and Livermore 2014). In the EU, the European courts are beginning to review IAs, and in some cases to remand regulatory actions for failure to conduct an IA (Alemanno 2009, discussing Case C- 310/04, Kingdom of Spain 
Wiener \& Ribeiro, Impact Assessment: Diffusion and Integration (DRAFT not for quotation - August 2014)

page 12

v. Council of the European Union (2006) (holding that failure to conduct an IA might, in certain circumstances, be a breach of the Proportionality Principle)). One ongoing effort to track judicial review of RIA across countries is the "Osservatorio AIR" ("RIA Observatory") in Italy (see http://www.osservatorioair.it/category/news/).

Judicial review of RIA may offer more potent enforcement measures (such as vacating a rule or enjoining a project) than executive ROBs may employ, but judicial review may also contribute to delay (as noted above regarding EIA), and courts may lack the expertise and political accountability embodied in executive ROBs (see Rachlinski and Farina 2002, and Seidenfeld 2002 (comparing the merits of expert vs. judicial review of agency regulation). Mendelson and Wiener (2014: 449, 471,519) review studies of agency efforts to circumvent judicial and executive review, and suggest that courts could rely more directly on executive expert review to evaluate arbitrariness and proportionality, e.g. deferring to a favorable review by the expert ROB as evidence that the agency action is non-arbitrary or proportionate.

\section{Diffusion of Impact Assessment}

Impact assessment is now being "diffused throughout the globe" (Radaelli and De Francesco 2008; See Table 1). So far, EIA has spread more broadly than RIA. Since its enactment, NEPA has strongly influenced the global diffusion of EIA. After the US, the first adopters of formal EIA systems were Canada and New Zealand (1973), Australia (1974), France (1976), Philippines (1977), Netherlands (1978), and Brazil (1981).

During the 1980s, two key developments in the process of diffusion of EIA were the EU EIA Directive in 1985 and the adoption of EIA by international development agencies and organizations (Sánchez 2006). The US Foreign Assistance Aid was amended in 1978 to include EIA requirements; in 1986, the OECD recommended that its member countries "actively support the formal adoption of an environmental assessment policy for their development assistance activities" (C(86)26/FINAL); and in 1989, The World Bank issued the Operational Directive (OD) 4.01, requiring EIA for its development projects. In its directive, the Bank designated the borrowing countries as primarily responsible for conducting the EIA for financed projects, which further spurred the diffusion of EIA among developing countries (Sadler 1996). Another landmark of the international diffusion of EIA was its inclusion in the 1992 Rio Declaration (Principle 17). EIA has now spread to more than 100 countries (Craik 2008: 23; De Francesco 2013). To be sure, the structures, functions and powers of EIA systems vary across these countries, in part due to their different underlying institutions (Craik 2008: 42-44).

Meanwhile, as the number of regulatory agencies worldwide has grown, especially rapidly since about 1990 (Levi-Faur 2011, fig. 1.4), the number of RIA systems and ROBs has also grown over that period. Institutions for regulatory oversight have spread from about half of the twenty-seven OECD members in 1998, to virtually all of the thirty-one OECD members in 2010 (Cordova-Novion and Jacobzone 2011, fig. 3) and to virtually all EU member states (De Francesco 2012, 2013).

In addition to US OIRA and the EU IAB, examples of ROBs in OECD member states include the Productivity Commission and the Office of Best Practice Regulation (OBPR) in Australia (where RIA has been employed since 1985); the Simplification and Better Regulation Unit in Denmark; the function of the Conseil d'Etat in supervising 
Wiener \& Ribeiro, Impact Assessment: Diffusion and Integration (DRAFT not for quotation - August 2014)

page 13

impact analyses pursuant to the Organic Law of April 15, 2009 in France; the Better Regulation Unit in Germany; the Administrative Evaluation Bureau in Japan; the Comisión Federal de Mejora Regulatoria (COFEMER) in Mexico; the Administrative Burdens Board in the Netherlands; the Regulatory Reform Committee (RRC) and Regulatory Reform Bureau in South Korea; and the Better Regulation Executive and associated regulatory committees in the United Kingdom (see the surveys in CordovaNovion and Jacobzone 2011; De Francesco 2013). In South Korea, spurred by an economic crisis in the 1990s, the government enacted the Basic Act on Administrative Regulations in 1998, and the RRC then undertook an extensive review of existing regulations resulting in thousands of revisions and repeals, as well as RRC oversight of RIAs for newly proposed regulations (Truen 2011; Cordova-Novion and Jacobzone 2011). In Chile, the economic evaluation requirement for environmental regulations (pursuant to Law 19,300 of 1994) has been supplemented by an ex post RIA process for enacted legislation, created in Law 20,416 of 2010, and nominally supervised by the Law Evaluation Department of the Chamber of Deputies; but so far that process has employed only a small staff and issued very few RIAs, and it remains unclear whether a robust ROB will supervise this RIA process (OECD 2011). Related systems exist or are being developed in other OECD members, including New Zealand, Poland, Portugal, Sweden, and Turkey (Cordova-Novion and Jacobzone 2011). In March 2012, the OECD issued a major set of 12 recommendations to all governments, advocating RIA for both ex ante (prospective) and ex post (retrospective) regulatory review; oversight by centralized ROBs; and international regulatory cooperation (OECD 2012a). In May 2012, President Obama issued Executive Order 13,609 to promote international regulatory cooperation. As noted above, the structures, functions and powers of these RIA systems and ROBs differ across countries. In a 2011 survey, slightly more than half of the ROBs in the OECD member states were empowered to review agency RIAs (Cordova-Novion and Jacobzone 2011, fig. 3). Some, like US OIRA, review administrative agencies' postlegislative proposed regulations; others, like the EU IAB, review initial proposals for legislation. This difference in RIA process derives from larger institutional differences in inter-branch (executive vs. legislative) structures and relations (Wiener and Alemanno 2010). "Return" authority is exercised by the U.S. OIRA (since 1981), the EU IAB (since 2010), the OBPR in Australia, the RRC in Korea, and COFEMER in Mexico, each of which must generally give a positive opinion for a proposed regulation to proceed (though there are exceptions in each system) (Cordova-Novion and Jacobzone 2011, table A.1). Others, like the Administrative Evaluation Bureau in Japan, the Administrative Burdens board in the Netherlands, and the Better Regulation Unit in Germany, can review the quality of RIAs but cannot return proposed regulations (Cordova-Novion and Jacobzone 2011, table A.1). Review of the existing stock of regulations (also known as ex post, retrospective, or "lookback" review) is being emphasized in the Australian regulatory oversight system (Australian Productivity Commission 2011), in Chile (OECD 2011), in the EU programs on smart regulation and regulatory fitness (European Commission 2010c, 2014b), and in the United States (under Executive Order 13,563 issued in 2011).

RIA and ROBs are also beginning to spread beyond the OECD to developing countries (Truen 2011; World Bank Group 2010; Jacobs 2006; Kirkpatrick and Zhang 2004). In many countries, as in the United States and EU, the development of cost- 
Wiener \& Ribeiro, Impact Assessment: Diffusion and Integration (DRAFT not for quotation - August 2014)

page 14

benefit analysis by academics and project-funding agencies preceded the creation of RIA applied to regulation and the establishment of ROBs to supervise regulatory RIAs.

Nudged by the OECD and the EU, countries becoming or seeking to become member states of the these organizations are adopting RIA: Croatia required RIA beginning in 2005, and created an RIA Coordination Office in 2007 (OECD 2009b, 21011), before joining the EU in 2013; Slovenia, which joined the EU in 2004, has created an RIA system, though without a centralized ROB (OECD 2012b); and Serbia, whose EU membership application remains under consideration, adopted Rules of Procedure requiring RIA for new legislation in 2005, after having established a Council for Regulatory Reform and Quality Control in 2003 (OECD 2009b, 245). But Bulgaria has hesitated to adopt RIA, despite internal support (Truen 2011). Turkey has adopted significant administrative reforms, partly in response to encouragement from the EU and partly for domestic reasons, but apparently has not yet instituted RIA (Sezen 2011). Several other countries are now moving to adopt formal systems of RIA and to establish ROBs. The use of cost-benefit analysis has become widespread across developing countries, often for government funded projects and increasingly for regulatory policies (Revesz and Livermore 2013; Quah and Toh 2012). Many countries adopted EIA before RIA (De Francesco 2013: 75). In Russia in 2008 and South Africa in 2009, the OECD held informational workshops on RIA. South Africa has moved ahead to develop a central RIA oversight unit attached to the Cabinet Office (World Bank Group 2010; Truen 2011). RIA was adopted for environmental regulations in Uganda in 2003 (UNEP 2005), and in Kenya in 2007 (World Bank Group 2010). In Brazil, the Civil House set up in 2007 the Program for the Strengthening of the Institutional Capacity for Regulatory Management (PRO-REG), which has coordinated the adoption and implementation of RIA by federal and state agencies. In 2013, Brazilian regulatory agencies issued the first rules creating a decentralized system of RIA (e.g., Resolução Normativa ANEEL n. 540/2013, and Resolução de Diretoria Colegiada ANCINE n. 52/2013). But a broader and more unified Brazilian RIA system, overseen by a central body, remains uncertain (Peci and Sobral 2011). The Philippines has an RIA process supervised by its National Economic and Development Authority, and is considering establishing an Office of Best Regulatory Practice to provide expert oversight and advice on this RIA process (Bird, Plunkett, and Bosworth 2010). Vietnam adopted RIA in 2008-9, with support from its Administrative Procedure Control Agency, the German GTZ, and the USAID's Vietnam Competitiveness Initiative (PERQ 2011; Truen 2011); an RIA is now required in Vietnam before a bill may be presented to the National Assembly (Truen 2011). The development of an RIA process for China's regulatory agencies remains a work in progress (Hu 2009).

These examples display an ongoing process of policy diffusion. The literature on the diffusion of policy ideas is large (see generally Rose 1993; Dolowitz and Marsh 2000; James and Lodge 2003; Busch and Jorgens 2005; Elkins and Simmons 2005; Berry and Berry 2007). Similar concepts of diffusion as an evolutionary process have been developed in many disciplines, including biology (Arnold 1997; Grant 1999; Deakin 2002), sociology (Rogers 2003), geography (Hagerstrand 1968), law (Sand 1971; Watson 1993; Tushnet 1999), political science (Walker 1969; Lazer 2005; Weyland 2005; Simmons et al. 2008), and history of science (Galison 1997). Legal scholars have borrowed from biologists the notion of "memes" as the unit, and counterpart of genes, in 
Wiener \& Ribeiro, Impact Assessment: Diffusion and Integration (DRAFT not for quotation - August 2014)

page 15

the evolution of ideas (Dawkins 1976; Deakin 2002). In biology, evolution was first understood to occur through mutations and competition among individuals within a species; later, through field studies, biologists began to appreciate that evolution also occurs through the exchange of genetic material across species via interbreeding (called "hybridization") (Arnold 1997; Grant 1999). Likewise, in law, evolution was initially understood to occur through competition among individual rules within a legal system (Priest 1977; Elliott 1985; Farber 1994; but for doubts about the efficiency of such legal evolution, see Hadfield 1993; Roe 1996); later, through the equivalent of field studies, legal scholars came to appreciate that legal evolution also occurs through the exchange of legal concepts across legal systems via borrowing (Watson 1993; Elliott 1997; Wiener 2001; Deakin 2002; Wiener 2003), which has also been dubbed "hybridization" (Wiener 2003, 254-61; Wiener 2006; Wiener et al. 2011, 541-44; Delmas-Marty 2006, 101-12). In our "networked" global society (Castells 2000; Slaughter 2004), the rate and importance of diffusion of ideas are increasing (Slaughter 2009), including or especially in the emerging community of "global administrative law" (Kingsbury et al. 2005).

Diffusion of policy innovations may occur in several ways and among many different actors (Levi-Faur 2005; Lazer 2005). A basic idea can vary as it is adapted for implementation in different places. Ideas may evolve as they spread and may be employed differently in different institutional settings; and the adoption of a policy innovation may also spur change in the adopting institutions. EIA or RIA adopted in one country may have a different institutional role and analytic content than EIA or RIA adopted in other countries (Radaelli 2005; Craik 2008; Wiener and Alemanno 2010). Careful comparison of the elements of each system, and histories of the behavior and statements of the actors involved, are needed to identify what precisely was borrowed by whom and from whom, and how it was then used. De Francesco (2013: 154) finds that implementation of RIA is influenced by the existing institutional structures and legal traditions in each country. And even if the legal idea is the same in each place we observe it arising, diffusion is not the only explanation; it might, for example, have arisen independently in each place in response to similar but independent conditions (as in "convergent evolution" and related concepts in biology, see Losos 2011). A policy idea that appears in more than one polity may be the result of various mechanisms, such as similar but independent responses to similar problems; purposeful learning and transnational borrowing; unexamined emulation or imitation; competition; and coercion (Elkins and Simmons 2005; Simmons et al. 2008). Dobbin, Simmons, and Garrett (2007: 462-63) distinguish "simple diffusion" (e.g. parallel independent solutions, or unexamined emulation) from "learning" which requires "evidence of the efficacy of a policy innovation before second- and third- movers adopted it. ... [R]ational learning theory implies a kind of cost-benefit analysis." Successful legal borrowing involves such a cost-benefit judgment that the decision to borrow will advance the adopter's interests (Wiener 2001; Levi-Faur 2005; Stone 2012; Ovodenko and Keohane 2012).

In the diffusion of EIA and RIA across countries, there is evidence of both similar responses to similar problems, and purposeful learning and borrowing of ideas. First, as discussed above, in each country there is growing demand for policy foresight: for tools to envision the future consequences of policy choices, to improve the design and outcomes of government projects and policies, and to equip the center of government to manage the growing array of government agencies. These are illustrated in the U.S. by 
the enactment of the Administrative Procedure Act in 1946 following the New Deal regulatory expansion, the enactment of NEPA in 1969 following the growth of federal project finance, and the creation of OIRA and the promulgation of executive orders on regulatory review (and the growth of judicial review of agency action) in the 1970s and 1980s following the burst of regulatory legislation of the preceding decade. Similarly, in Europe, the Better Regulation initiative and the IAB arose after the growth of EU level regulation in the 1990s. Second, there is evidence of conscious borrowing. European leaders expressly cited the American RIA system as their inspiration for learning and borrowing: "Better Regulation is a core theme of our EU Presidency ... There is a long tradition in American Public Administration of focusing on the quality and impact of regulation. ... There is much that we have learned from the United States in relation to regulatory management ... We hope too that there will be shared learning" (Ahern 2004, quoted in Wiener 2011: 543). Further, the OECD itself has been a major supplier of information and encouragement on regulatory quality improvement in the OECD member states and around the world. De Francesco $(2012,2013)$ found that trade relations and the country's legal system "family" were not significant predictors of RIA adoption; prior adoption of other information access laws helped predict RIA adoption; and the most influential factor in adoption of RIA was a country's connection to transnational information networks offering knowledge about regulatory innovations, notably the OECD itself. Allam (2013) also traced the role of the OECD in promoting RIA to its member states as well as to developing countries. But De Francesco (2013: 148-55) also found that, although countries' initial adoption of RIA was based on learning from other countries and through the OECD, countries have so far made less use of learning from other countries' experience regarding the subsequent implementation and evaluation of RIA.

This empirical history suggests that opportunities may be ripe for researchers to undertake comparative evaluation of RIA (and EIA) systems across countries, including both past and potential future borrowing. For example, the EU has consciously borrowed RIA from the US, but has designed its ROB, the IAB, differently from OIRA; what differences in outcomes are associated with these differences in design? (For an early comparative assessment, see Wiener and Alemanno 2010.) Researchers might study, among other elements, the differences between the EU IAB as a multi-member board vs. US OIRA as an office of career staff headed by a single administrator; OIRA's numerical thresholds for triggering and scaling review vs. the European concept of "proportionate analysis"; the quantification and monetized valuation methods in the US vs. those employed in the EU; the roles of ancillary impacts, distributional equity, and other factors in the IA methods employed each system; the institutional posture of OIRA review coming after agency action vs, the European RIA coming early in its legislative pipeline; and others. Analogous comparative studies can address the variation in IA systems across the US member states (Glaeser and Sunstein 2014; Schwartz 2010) and across the EU member states. And, as RIA and EIA continue to diffuse around the world, studying additional countries will offer a wider degree of variation across a larger number of observations with a wider range of institutional structures, and thus a stronger basis to discern patterns and draw inferences about the causes and consequences of this variation. This study of diffusion in IA systems can be an essential source of learning from 
Wiener \& Ribeiro, Impact Assessment: Diffusion and Integration (DRAFT not for quotation - August 2014)

page 17

variation and experimentation (Greenstone 2009; Wiener 2011: 551-552; Wiener and Alemanno 2015).

The diffusion of EIA and RIA also challenges the conventional view that legal differences across countries are entrenched or long-lasting, and are explained by discrete "national styles of regulation" (Vogel 1986), or separate "families" of legal systems (Zweigert and Kotz 1998), or ancient "legal origins" (La Porta et al. 2008). As Reimann (2001) pointed out, diffusion of legal ideas can erode the traditional categories of comparative law that assume discrete national legal systems. Vogel (2012) now concedes that national regulatory systems are far more open to wholesale change than he had previously argued (Vogel 1986). Even the "legal origins" advocates (La Porta et al. 2008), who have argued that modern business rules derive from ancient legal families (English, French, German, etc.), have also conceded (albeit very briefly) that "legal origins" may not account for regulations in what they label "new spheres of social control," nor for regulations adopted following crisis events (La Porta et al. 2008: 307, 326 ) - two of the leading characteristics of modern regulation and of associated EIA and RIA systems. (For critiques of the "legal origins" literature regarding business rules, see e.g. Roe 2006; Curran 2009; Michaels 2009; Klerman et al. 2011.) Contrary to the conventional claims of static "national styles," "families of law," and "legal origins," the reality is that regulation is now evolving through rapid learning and borrowing, in which ideas or elements are exchanged and legal systems undergo hybridization (Levi-Faur 2005; Wiener 2011, 2013). Countries and cultures previously caricatured as sharply different turn out to share a great deal (Baldwin 2009). Amid such hybridization, claims of discrete and static national legal systems turn out to be obsolete or misleading stereotypes.

This does not mean that no comparisons can be made. That countries are borrowing and hybridizing does not justify what Siems $(2007,1,6)$ critiques as the claim of the "end of comparative law." Comparisons can and must be made, but on the basis of more systematic empirical study of the permutations of specific rules, institutions and instruments of legal systems, rather than overgeneralizing to broad "national styles" based on a small and biased sample (Reimann 2001; Wiener 2011). Improved understanding will compare rules, doctrines, instruments and institutions as memes or modules that can be exchanged across interconnected legal systems.

\section{Integration of Impact Assessment}

The diffusion of EIA and RIA around the world reveals variation across countries, and variation across the types of impact assessment. Experience with such variation presents an opportunity to learn about the performance of different institutional designs and analytic methods (Wiener 2011: 551-552; Wiener and Alemanno 2015), and to consider whether these diverse types of impact assessment should be integrated into (or move part way toward) a unified approach. Fragmentation of IA systems can yield gaps (inadequate IA), overlaps (duplicative IA), and conflicts (frictions between IA systems). Further, even if each country adopted a single integrated comprehensive system of IA that overcame such fragmentation internally, the diffusion of IA across countries itself poses a geographic divide, if national IA systems focus only on domestic impacts. As we discuss below, integration of IA could offer several advantages, including better ensuring 
Wiener \& Ribeiro, Impact Assessment: Diffusion and Integration (DRAFT not for quotation - August 2014)

page 18

that decision makers consider the full portfolio of important impacts of their decisions (Porter and Rossini, 1983; Graham and Wiener, 1995; Wiener 2006; Stern and Wiener 2008; Revesz and Livermore 2008); reducing the costs of duplicative assessment processes; and organizing a more coherent institutional structure and process for the review of IAs. Yet it would also pose challenges, such as requiring a potentially difficult transition from the current fragmented array of multiple IA systems. And it would need to be adapted to the different institutional structures in different countries.

\section{A. Dimensions of Integration}

Evaluating the integration of diverse IA systems into a combined or single comprehensive approach to IA requires an understanding of the key dimensions on which impact assessment tools vary. We need to understand what mechanisms would be brought together and through what types of institutions.

A first dimension for differentiation of impact assessments is the object, or the kind of action that triggers the IA requirement. IA systems in different countries may apply to different actions from different agencies. As discussed above, the four existing systems of EIA and RIA in the US and the EU vary in the object that triggers the IA requirement. The object can be defined by the topic of its impacts (e.g., environmental, health, financial, social), the magnitude of its impacts (e.g., "major", or "significant," or with annual costs of more than $\$ 100$ million, or a sliding scale of proportionate analysis), and who performs the action (e.g., administrative agencies and/or the legislature). Integration of IA tools based on the object dimension can mean expanding the range of actions that trigger the IA requirement (potentially covering all of the topics, magnitudes, and actors who perform IA). Or some limits on this range of objects could be designated. The object of IA could also differ at different levels through the "policy cycle," for example, from requiring IA of only the largest proposals for legislation, to IA of both large and medium administrative regulatory actions, to IA of all significant spending projects. Given a broad array of impacts and levels of decision, "tiering" facilitates this dynamic. The idea of tiering originates in the context of EIA/SEA, with early roots in the 1978 CEQ Regulations. It represents one of the main drivers for the development of SEA (Arts, Tomlinson, and Voogd 2005), based on the premise that the overall policy outcome is most efficiently achieved by improving the interconnections among information, monitoring, and follow up, produced or conducted at the different levels of policies, plans, programs and projects. Tiering promises to improve the use of time and resources as data and analysis are shared, enabling IA at one stage of the policy cycle to draw on findings from other stages of IA.

A second dimension on which impact assessment tools may be differentiated is their content, or the types of impacts to be assessed. The content of an IA system may evolve over time, adding new sets of impacts that had not initially been within its scope (Gibson 2006). It is important to distinguish how the topical type of impacts can relate separately to both the definition of the object and the content of the IA. For instance, the 1978 CEQ regulations provided that only impacts on the "human environment" trigger the EIA requirement (interpreting those "comprehensively" to include "the natural and physical environment and the relationship of people with that environment"), but also provided that once such EIA is required, the content of the EIA should assess not only physical environmental impacts but also social and economic impacts) (40 CFR 
Wiener \& Ribeiro, Impact Assessment: Diffusion and Integration (DRAFT not for quotation - August 2014)

page 19

§1508.14; see NRC v. People Against Nuclear Energy, 460 U.S. 766 (1983), holding that psychological impacts do not trigger EIA under NEPA). Content integration means expanding the scope of the direct and indirect impacts assessed by the same IA tool once it is triggered. Notably, it means covering the full array of types of impacts, and both intended and unintended (ancillary) impacts (Graham and Wiener 1995; Revesz and Livermore 2008).

A third dimension of differentiation among IA systems refers to the analytical methods used during the IA process: for defining what impacts and alternatives will be assessed, measuring their magnitude and significance, enabling commensurability across diverse types of impacts, assessing mitigation options, and comparing or selecting among alternatives. At each point, the degree of attention to target impacts and ancillary impacts of the action (both countervailing harms and co-benefits) may vary across IA systems (Graham and Wiener 1995; Wiener 1998; Wiener 2002; Stern and Wiener 2008; Revesz and Livermore 2008). Cost-benefit analysis (CBA) is one prominent method used to translate important but diverse impacts into the same numeraire (e.g., valuation by monetizing, such as in dollars or euros) in order to assess these impacts comprehensively and on net. Countries may vary in the methodology of CBA and the inputs they use for valuation, adopt combinations of CBA with new elements, or follow alternative approaches. New developments in welfare economics and social choice theory seek to employ the numeraire used in CBA (monetization) to include, quantify and monetize important factors that had previously been omitted from monetized CBA, such as fair distribution, quality of life, and happiness (Adler 2012; Dolan and Peasgood 2008; Dolan and White 2007; Adler and Posner 1999).

Full integration of IA would mean the expansion of object, content, and method so that a single IA would incorporate all of these dimensions. (This could still require different (albeit connected) applications of the single IA approach to each stage of decision making (such as legislation, regulation, policies, plans, programs, and projects).) For example, one expansion from current American practice could be requiring and conducting IA for spending project decisions that pose significant social or economic impacts, even when they do not pose significant environmental impacts (and hence fall outside the object trigger of EIA under NEPA). This broader application of IA is the ambition of performance evaluation of spending programs (CEA 2014). Meanwhile, the careful attention to alternatives practiced in EIA could be used to expand alternatives analysis in RIA. RIA ostensibly already considers not only economic but also social and environmental impacts, but integration of EIA and RIA (along with other types of IA) could ensure balanced attention to all of these, as well as to distributional fairness, happiness (e.g. life satisfaction), and other measures of social well-being. (Integrated IA need not mean reducing every assessment to a single aggregate number.) Integration of RIA and EIA could also broaden the reach of IA by removing the exemptions that have been adopted to each (such as the statutory and judicial exemptions to NEPA, noted above; this was advocated by Wiener and Graham 1995: 266). Another change could be the application of CBA or related social valuation methods (as currently practiced in RIA) to ensure full consideration and commensurability of the content of integrated IA (whereas EIA in the past has often assessed only the physical units of environmental impacts, thus hindering the weighing and ranking of different types of impacts - though this may be changing, as discussed below). A further expansion of the impacts covered 
in IA could be to include global (international, foreign or external) impacts as well as national (domestic or internal) impacts, in order to ensure that the full portfolio of impacts receives attention by the decision maker - both national government decision makers through their national IA systems, and international decision makers (such as treaty regimes and intergovernmental organizations) through their own IA systems.

A fourth dimension on which IA systems may differ is the institution for review. As discussed in greater detail above, EIA tends to be reviewed by courts, whereas RIA tends to be reviewed by regulatory oversight bodies (ROBs) such as US OIRA or the EU IAB (although as previously noted, the failure to conduct an IA, and the content of an IA, may be considered by courts in their distinct review of arbitrariness or proportionality). Fully integrating IA systems would mean designing a coherent review process to review the single IA. The best reviewing institution might differ depending on the actor whose IA is being reviewed (e.g., a legislature vs. an administrative agency), and the underlying institutional structure of the polity, as further considered below.

\section{B. Progress toward Integrated Impact Assessment}

Competing trends of fragmentation and integration of EIA and RIA have developed within and across countries. NEPA itself can be understood as a successful effort of (content) integration, compared to the prior more generic process of reasoned rulemaking required by the APA: EIA under NEPA was designed to force federal agencies to consider previously neglected environmental impacts resulting from their major actions (Stewart 1975; Wiener and Graham 1995: 268-69) (see Scenic Hudson Preservation Conf. v. FPC, 354 F.2d 608 (2d Cir. 1965), cert. denied, 384 U.S. 942 (1966); Calvert Cliffs Coordinating Committee (D.C. Cir. 1971), cited above). Another salient EIA object- and content-integration was promoted eight years after the passage of NEPA, by CEQ guidelines: informal agency rulemaking was also defined as a "major federal action" for the purpose of triggering the EIA (40 CFR §1508.18(a) and $\$ 1508.5(\mathrm{~d})$ ), and the mandatory content of the EIA was expanded to include, in addition to physical environmental impacts, also aesthetic, historic, cultural, economic, social, safety, or health impacts, whether direct, indirect, or cumulative (40 CFR $\S 1508.8$ and $\S 1508.27(2)$ ) (McDermott 1979). This same phenomenon of content integration by expansion is widely perceived in other jurisdictions throughout the evolution of the EIA (Hugé and Waas 2011). EIA under NEPA is also moving toward incorporating monetized valuations of environmental impacts, as courts hold that an agency providing an economic valuation of a project's economic benefits must also provide a similar economic valuation of project's environmental impacts, such as by monetizing its greenhouse gas emissions using the "social cost of carbon" (see e.g. Center for Biological Diversity v. NHTSA, 538 F.3d 1172, 1200 (9th Cir. 2008); High Country Conservation Advocates v. U.S. Forest Service (D. Colo. June 27, 2014)).

RIA has also exhibited moves toward integration. While the object trigger for RIA in US Executive Order 12,2291 was an impact of at least \$100 million, in 1993 the new Executive Order 12,866 gave OIRA broader authority to review agency actions that raise an important legal question or that "adversely affect in a material way the economy, a sector of the economy, productivity, competition, jobs, the environment, public health or safety, or State, local, or tribal governments or communities" (Section 3(f)); and in the EU, the IA Guidelines cover any action on the Commission's annual Work Programme 
subject to the sliding scale principle of "proportionate analysis" (Wiener 2006). Further, both the US and EU have paid increasing attention to ex post or retrospective RIA, with US Executive Order 13,563 calling on agencies to develop retrospective analysis of existing rules, and some developing countries (e.g., in Chile) also adopting retrospective assessment of legislation.

As to RIA content, critics have argued that economic costs have been given greater weight in RIA than have social and environmental benefits (Ackerman and Heinzerling 2004; Achtnicht, Rennings, and Hertin 2009). Yet in both the US and the EU, the content of RIA is officially defined to include social and environmental impacts: Executive Orders 12,866 (1993), 13,563 (2011), and OMB Circular A-4 (2003) expressly direct the RIA to assess all important impacts, of any type (economic, social, health, environmental), and including distributional equity and ancillary impacts; and the EU IA Guidelines (2009) do likewise. .

In the EU, before the adoption of integrated impact assessment in 2002, DG Enterprise and Industry and DG Environment had advocated the adoption of two separate IA tools - the Regulatory Impact Assessment (RIA) and the Sustainability Impact Assessment (SIA). A compromise was reached in favor of a single (integrated) impact assessment, combining the elements of both sectoral tools (Melloni 2013). (EIA does remain a separate tool in the EU, as described above.) The adoption of a single IA tool is also consistent with the complementary nature of the EU Sustainable Development Strategy and the EU's Lisbon Strategy for economic competitiveness (see European Commission 2010a, observing that climate and energy issues made "the distinction between the Lisbon and Sustainable Development Strategies start[] to blur"). Recently, the European Commission has called for greater integration of IA methods, via improving the use of cost-benefit analysis in ex ante IA (Renda et al. 2013).

There have been moves to expand IA to cover global (international, external) as well as domestic (national, internal) impacts. In the US, EIA covers transboundary or external impacts as well as internal impacts of federal agency actions, through a combination of NEPA law (CEQ 1997) and Executive Orders 12,114 (1979) and 13,141 (1999) (see Schiffer 2004); and RIA also covers both (although OMB Circular A-4 (2003) instructs agencies to identify domestic and international impacts separately). Climate change is among the most significant type of impacts now being integrated into the content and analytic methods of IA, both in EIA (Burdge 2008; Center for Biological Diversity, cited above; High Country Conservation Advocates, cited above), and in RIA (in the US through the "social cost of carbon" estimate produced by an interagency working group in 2010 and updated in 2013).

On the other hand, there has been a parallel increase in the fragmentation of IA systems by type of object topic. Porter and Rossini identified 11 different IA tools, and cautioned "[ $t]$ he family of impact assessment types appears to be growing without regard for population control. Indeed, we do not have a good grasp on the true extent of the family. ... What is common, and what is different for these?" (Porter and Rossini 1983). In 1998, another study identified 28 different IA tools (Porter and Fittipaldi 1998); and in 2004, a study identified 128 IA tools - an increase of more than ten times the 1983 count (Vanclay 2004). One significant example of (object) fragmentation is the creation of SEA: as opposed to following the US CEQ example and integrating the object of EIA by expanding it to include the assessment of policies, plans, and programs (as well as 
projects and rulemakings), the EU and its member states decided to create a separate IA tool, the SEA. Not long after the EU adopted its EIA Directive in 1985, the EC Fourth Action Program on the Environment (1987) expanded the Commission's environmental review to cover policy and policy statements, plans and their implementation, procedures, programs, and projects.

Further, fragmented IA tools have been institutionalized, in addition to EIA and RIA, as supplemental requirements of governmental decision and rulemaking processes. Some examples at the US federal level include the regulatory flexibility analysis (assessing significant economic impacts on small entities) (5 U.S.C. 601-612), information collection analysis (44 U.S.C. 3501-3520), unfunded mandate analysis (2 U.S.C. Chs. 17A, 25), takings impact analysis (E.O. 12,630), assessment of environmental health or safety effects on children (E.O. 13,045), federalism impact assessment (E.O. 13,132), tribal impact assessment (E.O. 13,175), and energy effects assessment (E.O. 13,211) (see Lubbers 2012). Other important topics sought to be added to IA include human rights (Kemp and Vanclay 2013) and human dignity (Sunstein 2013b). Some of these fragmented IA tools arise from political constituencies seeking special consideration, and some arise from the multiple epistemic communities working to develop evaluation processes and methods to identify, measure, and assess the significance of different kinds of impacts. Often, these communities exist in parallel to each other (Pope et al. 2013), each developing its own IA tool and not paying attention to the common roots of IA or to the consequences of IA fragmentation.

Recently, the EIA literature and research community have begun to react to the congestion of multiple fragmented IA tools and the need for "cutting green tape," i.e. initiatives to streamline the application of different types of IA, citing Australia, South Africa, and Canada as examples (Pope et al. 2013). A recent paper highlights the proliferation of numerous IA types at the expense of demonstrated value in improving decisions, and calls for integration (Morrison-Saunders et al. 2014).

\section{Advantages of Integrated Impact Assessment}

Good foresight and decision making favor integrating impacts into a full portfolio analysis that shows the decision maker the full scope of important impacts (Franklin 1772; Sunstein 2000; Wiener 2002; Stern and Wiener 2008). Fragmented IA systems, as discussed above, may yield gaps, overlaps, and conflicts. Objections to integrating IA may include concerns about reducing the emphasis placed on the environmental, small business, takings, federalism, energy, or other specific impacts which are the special focus of fragmented IA systems (Mutombo 2012; Pope, Annandale, and MorrisonSaunders 2004) - indicating that specialized impact assessment is seen as an advocacy tool promoted by a group that wants to advance its own interest or correct the neglect of its interest (Morrison-Saunders and Fischer 2006). Yet fragmented IA systems and fragmented policy institutions may omit or disregard weaker voices and may conceal important tradeoffs and synergies, hence failing to represent all affected interests (Stewart 1975; Wiener and Graham 1995; Stewart 2014). And specialized IA for each different topic may lead to neglect of some types, or conflict among types (as between RIA and EIA), and possibly biased emphasis to each type in each separate process, whereas integrated IA could foster more constructive evenhanded analysis and deliberation. Demands for policy foresight, comprehensive decision analysis, confronting trade-offs, 
reducing the costs of duplicative processes, and enhancing democratic pluralism may thus push IA systems and decision makers to consider all important impacts together in a more integrated approach to IA . Targeting only one kind of impact in each assessment and leaving other impacts to a different tool or process only undermines the function of IA to develop an accurate measure of the full, cumulative impacts. It omits interactions among different types of impacts, including countervailing harms (risk-risk tradeoffs) and cobenefits (Graham and Graham 1995; Revesz and Livermore 2008) -- which might even distort the assessment of the target impact if its magnitude depends on interactions with other factors. The core aspiration of EIA and RIA was to ensure that government decision makers stop and think about the full, systemic, interconnected effects of their options, yet exclusion or isolation of different impacts in separate IAs is tantamount to arbitrarily defining the system boundary and thereby embedding blinders from the outset (Suh et al. 2004). A key advantage of content-integrated impact assessment is to provide a comprehensive platform for oversight, overcoming narrow cognitive heuristics and political biases, forcing the decision maker to explicitly confront all the relevant impacts, benefits and trade-offs in the same (transparent) process, explaining its reasoning in the same document or report.

Meanwhile, integrating IA could reduce duplicative overlap and delays, compared to multiple IA systems. In the US, both RIA and EIA apply to rulemaking, which offers an interesting and puzzling case study of overlap. Even if both RIA and EIA cover the same content (types of impacts), they employ different methods to evaluate alternatives: RIA usually uses cost-benefit or cost-effectiveness analysis, while EIA usually does not (despite the early call for CBA in EIA, see Calvert Cliffs Coordinating Committee, later rescinded in Strycker's Bay, both cited above). This difference in evaluation method may yield different results. An integrated IA system could enable analysts and decision makers to reduce the overlap or fragmentation of these two systems, while demanding that they reconcile decision criteria. Gaps in the current systems for EIA (such as exemptions from NEPA, in the US) and RIA could be overcome by establishing an Integrated IA system that covers all important impacts.

An integrated impact assessment process might be costly to undertake, because of greater information demands and the greater time needed for broader analysis; but it could also cost less in time and expense than a set of smaller parallel fragmented and divergent or redundant impact assessments, each with its own opportunities for government units or interest groups to induce delay. Furthermore, if separate fragmented IA tools neglect the interactions and feedbacks among types of impacts, the result might be inaccurate assessment of the target impact, and unexpected adverse outcomes down the road, yielding outcry and litigation by affected groups, and ultimately necessitating greater cost, disruption and delay to re-assess these interactions and revise the decision. Assessing all interacting impacts of the same action in one IA provides a better opportunity for accurately defining the system, the full portfolio of multiple consequences of each alternative, and the best path forward, reducing the need for subsequent disputes, re-assessments and course changes.

Moreover, as to public participation, separating impact assessments of the proposed action into multiple different specialized IA processes may weaken the interest and motivation of the public in becoming actively involved in submitting comments, attending public hearings, and offering suggestions. Fragmented IA may lead to 
participatory fatigue, when multiple or successive assessment processes take place for the same action (Hoffman et al. 2013). The same could be said about interagency consultation: the more impact assessment processes there are, the more costly it will be to other agencies to present detailed comments on the proposed action and its alternatives. Further, fragmented IA lets each interest group or agency speak only to its own topic area, and misses the opportunity - potentially offered by integrated IA - to bring varied interest groups and agencies together to deliberate, hear each other's perspectives, reconcile their conflicts (Croley 2008), and develop creative solutions that meet multiple objectives in concert (what Graham and Wiener 1995 called "risk-superior solutions"). Ideally, public participation in integrated IA could be a powerful source of creativity and design of alternatives (Sunstein 2013b).

To be sure, because the world changes over time, IAs may need to be supplemented to account for new information. Thus the impact assessment process should be iterative, with each round including a review of how the alternatives of the proposed action were framed and assessed (in order to improve ex ante foresight methods in general, as well as to revise the particular IA and decision at issue). This iterative approach is a key feature of supplemental EIAs under NEPA, and of retrospective ex post RIAs. Iterative and retrospective IAs should foster more adaptive decision making, as further rounds of IA indicate desirable changes in policy decisions to address changing circumstances and knowledge. Fragmented impact assessments on different types of impacts for the same action, by contrast, make it more difficult to collect and distill this knowledge and to coordinate adjustments in decisions across distinct IA processes.

Finally, integrated impact assessment might also improve learning about IA across countries, disciplines, and professional areas, at least if the results of many IAs are collected and compared (Farber 2007). We need empirical research and experimentation to assess whether steps toward integrated IA have been or can be successful, where, and why. Evolving RIA approaches could be compared for their object triggers (e.g., thresholds vs. "proportionate analysis") and for their analytic methods (e.g., standard cost-benefit analysis, CBA with distributive weights, or other measures of subjective well-being). Meanwhile, EIA and SEA have enhanced awareness of physical impacts but remain in search of an operational method of measuring significance, valuing impacts, and ranking alternatives that pose trade-offs among objectives (Briggs and Hudson 2013; Lawrence 2007). New frontiers might be available for comparison and cross-fertilization across IA systems in different countries when every impact assessment tool comes to share the same core features for foresight and oversight.

\section{Challenges to Integrated Impact Assessment}

As discussed above in Parts I and IV, integrating the content (types of impacts) in IA can help ensure comprehensive analysis of the full portfolio of impacts, including ancillary impacts, interactions, synergies, and trade-offs. Meanwhile, integrating the methods used in IA can help combine decision criteria such as aggregate well-being and distributional equity, and can help address the complexity of the full portfolio of impacts.

It may be more challenging, however, to integrate impact assessments and review processes across different kinds of objects or actions. Even if RIA, EIA and other topical types of IA were combined into one integrated IA as to content and methods, actions as diverse as spending and regulation, or legislative and administrative action, may 
nonetheless warrant different processes for producing and/or reviewing the integrated IA. Current IA systems already illustrate the feasibility of some degree of object integration. IA in the EU applies to any kind of major Commission initiatives and those having the most important impacts (Melloni 2013), in addition to acts adopted by the Commission in the exercise of its implementing powers (Alemanno and Meuwese 2013). EIA in the US applies not only to government-funded projects, but also to agencies' permitting decisions for private projects, to agencies' informal rulemaking, and (at least nominally) to agencies' proposals for legislation. And SEA under the Espoo Convention applies to plans, programmatic actions, and policies. As detailed above, the review processes for RIA (by OIRA, and potentially indirectly by courts) and for EIA (by CEQ, EPA, and by courts) remain institutionally separated in the US. Integrating RIA and EIA across both regulatory policies and projects, and both administrative action and legislation, might require significant creativity, experimentation, and acculturation.

If an integrated impact assessment system were adopted for all kinds of government actions, a set of screening criteria would be needed to identify when the IA is triggered. In the US, this would involve reconciling (or replacing) the RIA criteria for a "significant regulatory action" (more than $\$ 100$ million impact, or material adverse effect on the environment or public health, or serious inconsistency with other government policy, or novel legal or policy issues) (EO 12,866, sec. 3(f)) and the EIA criteria for a "major federal action" potentially significantly affecting the human environment. In the EU, the IA criterion of "proportionate analysis" may already serve to screen all types of actions for different degrees of scrutiny along a sliding scale, although it still depends on some measure of relative significance. Along those lines, integrated IA would offer an opportunity to revisit the challenge of determining the extent and degree of detail that the assessment should apply to each potential impact (including ancillary impacts), once the impact assessment requirement is triggered.

Moreover, Integrated IA would highlight the challenge of weighing the significance of the impacts of each alternative. This evaluation is relevant both at the trigger stage (under NEPA, is an impact "significant" enough to trigger an EIA?) and later in any comparison or ranking of alternatives by their impacts or mitigation (under RIA to maximize net benefits, or under substantive EIA invoking a similar balancing test, how important are the impacts, weighed on a common metric or numeraire?) CEQ's 1978 NEPA regulations hinted at this need for weighing significance, but the Supreme Court's turn toward a "purely procedural" stance for NEPA (in Strycker's Bay and in Robertson, cited above) diverted EIA in the US toward a focus on physical measures of impact without the need to weigh their value; the move toward Integrated IA will demand and stimulate the development of analytic methods for weighing and evaluating impacts, perhaps focused on aggregate and sustainable welfare (as suggested in e.g. High Country Conservation Advocates, cited above).

Integrating impact assessment would also require choices about which institution would oversee the integrated IA. Would the Integrated IA be reviewed mainly by courts (as in EIA), or mainly by an expert executive body (as in RIA), or mainly by a new institution created to review the new integrated IAs? If the new Integrated IA system were to consolidate initial review in the executive branch (as the IAB reviews all proposals within the European Commission), there remain several options: for example, the US President could revise EO 12,866 to give OIRA the role of reviewing all of the 
new Integrated IAs from all agencies; or review of Integrated IAs of regulation could remain at OIRA while review of Integrated IAs of spending projects could be assigned to another executive office such as CEQ (a role CEQ already plays, when an EIA is referred to CEQ by EPA pursuant to section 309 of the Clean Air Act) or a new review office in the Budget side of OMB; or, an entirely new executive oversight body could be created to review all Integrated IAs (replacing this function at OIRA, CEQ, and other existing bodies). By contrast, courts could review the new Integrated IA (combining RIA plus EIA and other types), under the APA or under a new statute authorizing judicial review of the Integrated IAs. A further option is to do both executive and judicial review (as currently applies in the US to EIA, and indirectly to RIA): an executive office (such as OIRA, or OIRA for regulation plus another office for spending projects, or a new office for both) could conduct the initial and primary review of the Integrated IA, and then judicial review could also be authorized. These reviews could be streamlined by the integration across content and object, and the judicial review could be made more deferential to the agency if the Integrated IA has already received an approving review from the executive office (Mendelson and Wiener 2014).

Legislative IA raises further questions, at least in the US. In the EU, the IA process applies to proposals for legislation initiated by the Commission, with review by the IAB, and then additional IAs of amendments (and reviews of the IAB) by the IA Unit in the European Parliament. In the US, there is no routine IA of proposals for legislation (only RIA and EIA of administrative action, though NEPA does mention "proposals for legislation"). Applying an Integrated IA to legislative proposals in the Congress would raise several institutional questions, notably: which bodies should conduct or write such IAs, which objects or criteria should trigger the need to write an IA, and which oversight body should review such IAs? Congress could create such an IA process for itself, with its own newly created expert oversight body, or it could assign this oversight role to an existing expert office such as CBO or GAO or CRS, perhaps with input from ACUS. The Integrated IA could initially be written by each committee staff, triggered by a "major" bill being considered in that committee (or other factors tracking the process for advancing legislation), and then reviewed by the Congressional expert ROB - so long as the IA and its review can occur in time for the expertise to help inform members of Congress when they vote on the bill. Or such IAs could be written by the relevant expert executive agencies (as sometimes occurs already), at the request of key members of Congress or of key executive branch officials, and then reviewed by Congress (its members and staff, or a new Congressional oversight body), and/or by OMB (i.e. OIRA, and an OMB office on the Budget side, respectively). Or an entirely new IA institution, such as an "ombudsman" or "auditing board" (examples of which currently operate in Europe) could be created by Congress to handle IA of legislation (indeed such an independent ROB could even be enlarged to oversee IAs of agency regulation as well as IAs of legislation). An independent body could be created to conduct retrospective reviews (ex post IA) of existing laws and regulations. Other options may deserve consideration as well. (It seems less plausible that courts could review legislative IA, inserting judicial review into the highly political legislative process - which may explain why NEPA's mention of "proposals for legislation" has so rarely been raised in litigation.) There are some precedents for legislative IA in the US, including the CBO's budgetary evaluations (in cooperation with OMB's Budget side); studies on selected 
issues by GAO or CRS or National Academy of Sciences panels or executive agencies; and the Flood Control Act of 1936, which attempted to require CBA for annual Congressional approvals of water projects (Porter 1996). The EU's system of legislative IA should be studied for lessons to apply (or avoid) in the US. Moreover, in addition to ex ante legislative IA - or perhaps instead (if ex ante IA is too difficult to undertake during the legislative process) - ex post retrospective IA could be applied to existing legislation to enhance evidence-based performance evaluation (CEA 2014; Schuck 2014). Integrated IA plainly touches on issues rooted in the structures of political systems. Impact assessment of legislative and/or administrative action will inevitably have to fit into the constitutional and political structure of each legal system (Wiener and Alemanno 2010). There will thus be challenges in using IA throughout government (and across diverse countries) to promote transparency, accountability and foresight, and challenges in integrating across fragmented types of IA - yet also the potential for significant benefits from doing so. Experience across countries - through the diffusion of IA - will offer comparative insights into these options and their pros and cons. The analytic and institutional changes that Integrated IA might bring or require can present important opportunities for research, experimentation, and learning.

\section{Conclusions}

The international diffusion of impact assessment tools such as EIA and RIA reveals the growing demand for mechanisms to improve social outcomes, to manage the state, to promote transparency and accountability, and to enhance foresight. All around the world, governments are equipping themselves to think things through. Discrete national styles of regulation are giving way to interconnected networks exchanging and hybridizing regulatory ideas. But this diffusion also exhibits fragmentation, with a variety of different IA tools being employed to address different topics, using different analytic methods, triggered by different kinds of actions, and administered through different institutions. Beyond the current fragmented array of RIA and EIA (and many other types of IA) lies the possibility of Integrated IA -- a combined IA system addressing all types of actions and all types of impacts in a holistic full portfolio analysis. That path would pose significant challenges, but also offer significant benefits. As this evolutionary and hybridizing process unfolds, the variation we observe (across countries, institutions, and types of impact assessment) offers researchers an opportunity to compare design features in different settings, and learn how to improve these tools (Wiener and Alemanno 2015). We can also experiment with alternative approaches (Greenstone 2009). To foster careful study and learning, we should construct a global policy laboratory (Wiener 2011, 2013) that compares outcomes and tests policy innovations including existing and new variations of impact assessment. 
Wiener \& Ribeiro, Impact Assessment: Diffusion and Integration (DRAFT not for quotation - August

\section{References}

Achtnicht, Martin, Klaus Rennings, and Julia Hertin. 2009. "Experiences with Integrated Impact Assessment-empirical Evidence from a Survey in Three European Member States." Environmental Policy and Governance 19 (5): 321-35.

Ackerman, Frank, and Lisa Heinzerling. 2004. Priceless : On Knowing the Price of Everything and the Value of Nothing. New York: New Press.

ACUS (Administrative Conference of the United States). 2013. "Recommendation 2013-2: Benefit-Cost Analysis at Independent Regulatory Agencies." June 13. Available at http://www.acus.gov/research-projects/benefit-cost-analysisindependent-regulatory-agencies .

Adler, Matthew D. 2012. Well-Being and Fair Distribution: Beyond Cost-Benefit Analysis. New York: Oxford University Press.

Adler, Matthew D., and Eric A. Posner. 1999. "Rethinking Cost-Benefit Analysis." The Yale Law Journal 109 (2): 165-247.

Ahern, Bertie. 2004. Speech by the Taoiseach (head of government of Ireland), Bertie Ahern, at the IBEC Conference on EU-U.S. Perspectives on Regulation. April 19, Dublin. (accessed May 24, 2010).

Alemanno, Alberto. 2009. "The Better Regulation Initiative at the Judicial Gate - A Trojan Horse within the Commission's Walls or the Way Forwards?" European Law Journal 15: 382-401.

Alemanno, Alberto, and Anne Meuwese. 2013. "Impact Assessment of EU NonLegislative Rulemaking: The Missing Link in 'New Comitology." European Law Journal 19 (1): 76-92.

Allam, Miriam. 2013. "The Role of the OECD in Capacity Building for Public Governance". In The Globalization of Cost-Benefit Analysis in Environmental Policy, ed. Michael A. Livermore and Richard L. Revesz, 142-59. New York: Oxford University Press.

Arnold, M. L. 1997. Natural Hybridization and Evolution. Oxford: Oxford University Press.

Arts, Jos, Paul Tomlinson, and Henk Voogd. 2005. "EIA and SEA Tiering: The Missing Link." In International Experience and Perspectives in SEA", Conference of the International Association of Impact Assessment, 26-30. http://www.henkvoogd.nl/pdf/tiering.pdf.

Australian Productivity Commission. 2011, Identifying and Evaluating Regulation Reforms. Research Report, Canberra, December.

Baldwin, Peter. 2009. The Narcissism of Minor Differences: How America and Europe Are Alike. Oxford: Oxford University Press.

Becker, Dennis R., Charles C. Harris, William J. McLaughlin, and Erik A. Nielsen. 2003. "A Participatory Approach to Social Impact Assessment: The Interactive Community Forum.” Environmental Impact Assessment Review 23 (3): 367-82.

Bellinger, Ed. 2000. Environmental Assessment in Countries in Transition. Central European University Press.

Bentham, Jeremy. 1843. "Extracts from Bentham's Commonplace Book." In The Works of Jeremy Bentham, edited by William Tait, 10: 142. London: Simpkin, Marshall \& Co. 
Wiener \& Ribeiro, Impact Assessment: Diffusion and Integration (DRAFT not for quotation - August

Berkowitz, Daniel, Katharina Pistor, and Jean-Francois Richard. 2003. "Economic Development, Legality, and the Transplant Effect." European Economic Review 47: 165-95.

Berry, Frances Stokes, and William D. Berry. 2007. "Innovation and Diffusion Models in Policy Research.” In Theories of the Policy Process, ed. Paul A. Sabatier, -223260. Boulder: Westview Press.

Bird, Kelly, Herb Plunkett, and Malcolm Bosworth. 2010. Philippines: Options for Establishing an Office of Best Regulatory Practice. ADB Technical Assistance Consultant's Report, Project Number: 40538-01. Manila: Asian Development Bank.

Bond, Alan, Angus Morrison-Saunders, and Jenny Pope. 2012. "Sustainability Assessment: The State of the Art." Impact Assessment and Project Appraisal 30 (1): 53-62.

Briggs, Sam, and Malcolm D. Hudson. 2013. "Determination of Significance in Ecological Impact Assessment: Past Change, Current Practice and Future Improvements." Environmental Impact Assessment Review 38 (January): 16-25.

Burdge, Rabel J. 2008. "The Focus of Impact Assessment (and IAIA) Must Now Shift to Global Climate Change!!’ Environmental Impact Assessment Review 28 (8): 618-22.

Busch, Per-olof, and Helge Jorgens. 2005. "The International Sources of Policy Convergence: Explaining the Spread of Environmental Policy Innovations." Journal of European Public Policy 12: 860-84.

Castells, Manuel. 2000. The Information Age: Economy, Society, and Culture. 2nd ed. 3 vols. Oxford: Blackwell.

CEA (Council of Economic Advisers). 2014. "Evaluation as a Tool for Improving Federal Programs." Chapter 7 in Economic Report of the President. US Government Printing Office, Washington DC.

CEQ (Council on Environmental Quality). 1997. "Guidance on NEPA Analyses for Transboundary Impacts." July 1. Available at http://ceq.hss.doe.gov/nepa/regs/transguide.html , or http://www.gc.noaa.gov/documents/transguide.pdf .

Chambers, Simone. 2003. "Deliberative Democratic Theory." Annual Review of Political Science 6 (1): 307-26.

Chodosh, Hiram. 1999. "Comparing Comparisons: In Search of Methodology.” Iowa Law Review 84: 1025-1131.

Clausen, Alison, Hoang Hoa Vu, and Miguel Pedrono. 2011. "An Evaluation of the Environmental Impact Assessment System in Vietnam: The Gap between Theory and Practice." Environmental Impact Assessment Review 31 (2): 136-43.

Coglianese, Cary and Lori Snyder Bennear. 2005. "Program Evaluation of Environmental Policies: Toward Evidence-Based Decision Making," in Social and Behavioral Science Research Priorities For Environmental Decision Making (Washington, DC: National Research Council, National Academies Press) 24673.

Copeland, Curtis W. 2013. "Length of Rule Reviews by the Office of Information and Regulatory Affairs." Report for the Administrative Conference of the United States (ACUS), December 2. 
Wiener \& Ribeiro, Impact Assessment: Diffusion and Integration (DRAFT not for quotation - August

Cordova-Novion, Cesar, and Stephane Jacobzone. 2011. "Strengthening the Institutional Setting for Regulatory Reform: The Experience from OECD Countries." OECD Working Papers on Public Governance, No. 19.

Cosco, Jonathan M. 1998. "NEPA for the Gander: NEPA's Application to Critical Habitat Designations and Other 'Benevolent' Federal Action," Duke Environmental Law \& Policy Forum 8: 345-386.

Craik, Neil. 2008. The International Law of Environmental Impact Assessment. Cambridge and New York: Cambridge University Press.

Croley, Steven. 2003. "White House Review of Agency Rulemaking: An Empirical Investigation." Univ. of Chicago Law Review 70: 821-85.

Croley, Steven. 2008. Regulation and Public Interests: The Possibility of Good Regulatory Government. Princeton, N.J.: Princeton Univ. Press.

Curran, Vivian G. 2009. "Comparative Law and the Legal Origins Thesis." American Journal of Comparative Law 57: 863-76.

Datla, Kirti and Richard L. Revesz. 2013. "Deconstructing Independent Agencies (and Executive Agencies)." Cornell Law Review 98: 769-843.

Dawkins, Richard. 1976. The Selfish Gene. Oxford: Oxford University Press.

De Francesco, Fabrizio. 2012. "Diffusion of Regulatory Impact Analysis among OECD and EU Member States." Comparative Political Studies. http://cps.sagepub.com/content/early/2012/02/15/0010414011434297.

De Francesco, Fabrizio. 2013. Transnational Policy Innovation: The OECD and the Diffusion of Regulatory Impact Analysis. Colchester, UK: ECPR Press.

Deakin, Simon. 2002. "Evolution for Our Time: A Theory of Legal Memetics." Current Legal Problems 55: 1-42.

Delmas-Marty, Mirelle. 2006. Le Pluralisme Ordonné. Paris: Seuil.

Dobbin, Frank, Beth Simmons, and Geoffrey Garrett. 2007. "The Global Diffusion of Public Policies: Social Construction, Coercion, Competition, or Learning?" Annual Review of Sociology 33: 449-72.

Dolan, Paul, and Mathew P. White. 2007. "How Can Measures of Subjective Well-Being Be Used to Inform Public Policy?” Perspectives on Psychological Science 2 (1): 71-85.

Dolan, Paul, and Tessa Peasgood. 2008. "Measuring Well-Being for Public Policy: Preferences or Experiences?" The Journal of Legal Studies 37 (S2): S5-S31.

Dolan, Paul, Richard Layard, and Robert Metcalfe. 2011. "Measuring Subjective WellBeing for Public Policy." http://eprints.lse.ac.uk/35420/1/measuring-subjectivewellbeing-for-public-policy.pdf.

Dolowitz, David, and David Marsh. 2000. "Learning from Abroad: The Role of Policy Transfer in Contemporary Policy Making." Governance 13 (1): 5-24.

Eeckhoudt, Louis R. and James K. Hammitt. 2001. "Background Risks and the Value of a Statistical Life." Journal of Risk and Uncertainty 23: 261-279.

Ekelund, Robert B., Jr., and Robert F. Hebert, 1975. "Dupuit and Marginal Utility: Context of the Discovery." History of Political Economy 8: 266-73.

Elkins, Zachary, and Beth Simmons. 2005. "On Waves, Clusters, and Diffusion: A Conceptual Framework." Annals of the American Academy of Political and Social Science 598: 33-51. 
Wiener \& Ribeiro, Impact Assessment: Diffusion and Integration (DRAFT not for quotation - August

Ellerman, A. Denny, Frank Convery, and Christian de Perthuis. 2010. Pricing Carbon: The European Union Emissions Trading Scheme. Cambridge: Cambridge University Press.

Elliott, E. Donald. 1985. "The Evolutionary Tradition in Jurisprudence." Columbia Law Review 85: 38-94.

Elliott, E. Donald. 1997. "Law and Biology: The New Synthesis?" St. Louis University Law Journal 41: 595-624.

European Commission. 2010a. "Lisbon Strategy Evaluation Document". Commission Staff Working Document, SEC(2010) 114 final (2 February). Available at: http://ec.europa.eu/archives/growthandjobs_2009/pdf/lisbon_strategy_evaluation_ en.pdf.

European Commission. 2010b. Communication from the President: The Working Methods of the Commission 2010-2014. C(2010) 1100 (10 February). Available at: http://ec.europa.eu/commission_20102014/president/news/documents/pdf/c2010_1100_en.pdf .

European Commission. 2010c. Communication from the Commission: Smart Regulation in the European Union. $\mathrm{COM}(2010) 543$ final (8 October).

European Commission. 2013. Impact Assessment Board Report for 2012. (January 2013). Available at http://ec.europa.eu/smart-regulation/impact/iab/iab_en.htm or http://ec.europa.eu/smartregulation/impact/key_docs/docs/iab_report_2012_en_final.pdf .

European Commission. 2014a. Impact Assessment Board Report for 2013. (January 2014). Available at http://ec.europa.eu/smartregulation/impact/key_docs/docs/iab_report_2013_en.pdf

European Commission. 2014b. Communication from the Commission: Regulatory Fitness and Performance Programme (REFIT): State of Play and Outlook \{SWD(2014) 192 final\}. COM(2014) 368 final (18 June).

Farber, Daniel A. 2007. "Bringing environmental assessment into the digital age." In Taking Stock of Environmental Assessment: Law, Policy and Practice, eds. Jane Holder and Donald McGillivray. London: Routledge Cavendish.

Farber, Daniel A. 1994. "Environmental Protection as a Learning Experience." Loyola of Los Angeles Law Review 7: 791-807.

Franklin, Benjamin. 1772. "Letter to Joseph Priestley, September 19." Reprinted in Benjamin Franklin: Representative Selections, with Introduction, Bibliography and Notes, ed. Frank Luther Mott and Chester E. Jorgenson, 348-49. New York: American Book Company.

Galison, Peter. 1997. Image and Logic: A Material Culture of Microphysics. Chicago: University of Chicago Press.

Gibson, Robert B. 2006. "Sustainability Assessment: Basic Components of a Practical Approach.” Impact Assessment and Project Appraisal 24 (3): 170.

Gilbert, Daniel T., and Timothy D. Wilson. 2007. "Prospection: Experiencing the Future." Science 317: 1351-54.

Glaeser, Edward L., and Cass R. Sunstein. 2014. "Moneyball for State Regulators." National Affairs, issue 20 (Summer). Godard, Olivier, Claude Henry, Patrick Lagadec, and Erwann Michel-Kerjan. 2002. Traité des Nouveaux Risques: Précaution, Crise, Assurance. Paris: Gallimard. 
Wiener \& Ribeiro, Impact Assessment: Diffusion and Integration (DRAFT not for quotation - August

Graham, John D. 2007. "The Evolving Regulatory Role of the U.S. Office of Management and Budget." Review of Environmental Economics and Policy 1: $171-91$.

Graham, John D., and Jonathan B. Wiener, eds. 1995. Risk vs. Risk: Tradeoffs in Protecting Health and the Environment. Cambridge: Harvard University Press.

Grant, Peter R. 1999. Ecology and Evolution of Darwin's Finches. Princeton: Princeton University Press.

Greenstone, Michael. 2009. "Toward a Culture of Persistent Regulatory Experimentation and Evaluation." In New Perspectives on Regulation, ed. David Moss and John Cisternino, 111-125. Cambridge: Tobin Project.

Hadfield, Gillian. 1993. "Bias in the Evolution of Legal Rules." Georgetown Law Journal 80: 583-616.

Hagerstrand, Torsten. 1968. "The Diffusion of Innovations." In International Encyclopedia of the Social Sciences, ed. David L. Sills, 4: 174-78. New York: Macmillan.

Hines, Lawrence G. 1973. "Precursors to Benefit-Cost Analysis in Early United States Public Investment Projects." Land Economics 49: 310-17.

Hoffman, Steven M., Shane Fudge, Lissa Pawlisch, Angela High-Pippert, Michael Peters, and Joel Haskard. 2013. "Public Values and Community Energy: Lessons from the US and UK." Sustainability 5 (4): 1747-63.

$\mathrm{Hu}$, Jiabin. 2009. "Assessing the Governance of the Independent Regulatory Agencies in China." PhD diss., University of Southern California.

Hugé, Jean, and Tom Waas. 2011. "Converging Impact Assessment Discourses for Sustainable Development: The Case of Flanders, Belgium.” Environment, Development and Sustainability 13 (3): 607-26.

Jacobs, Scott. 2006. Current Trends in Regulatory Impact Analysis: The Challenges of Mainstreaming RIA into Policy-Making. New York: Jacobs \& Associates.

James, Oliver, and Martin Lodge. 2003. "The Limitations of 'Policy Transfer' and 'Lesson Drawing' for Public Policy Research.” Political Studies Review 1: 17993.

Kagan, Elena. 2001. "Presidential Administration." Harvard Law Review 114: 22452385.

Katzen, Sally. 2011. "OIRA at Thirty: Reflections and Recommendations," Administrative Law Review 63: 103 - .

Kemp, Deanna, and Frank Vanclay. 2013. "Human Rights and Impact Assessment: Clarifying the Connections in Practice." Impact Assessment and Project Appraisal 31 (2): 86-96.

Kingsbury, Benedict, Nico Krisch, and Richard B. Stewart. 2005. "The Emergence of Global Administrative Law." Law and Contemporary Problems 68 (3): 15-62.

Kirkpatrick, C., and Y. Zhang. 2004. "Regulatory Impact Assessment in Developing and Transition Economies: A Survey of Current Practice.” Working Paper Series, No. 83, Centre on Regulation and Competition, Institute for Development Policy and Management, University of Manchester.

Kirkpatrick, Colin and David Parker, eds. 2007. Regulatory Impact Assessment: Towards Better Regulation? Cheltenham, UK: Edward Elgar. 
Wiener \& Ribeiro, Impact Assessment: Diffusion and Integration (DRAFT not for quotation - August

Klerman, Daniel M., Paul G. Mahoney, Holger Spamann, and Mark I. Weinstein. 2011. "Legal Origin or Colonial History?" Journal of Legal Analysis 3: 379-409.

Kysar, Douglas A. 2010. Regulating from Nowhere: Environmental Law and the Search for Objectivity. New Haven Conn.: Yale University Press.

La Porta, Rafael, Florencio Lopez-de-Silanes, and Andrei Shleifer. 2008. "The Economic Consequences of Legal Origins." Journal of Economic Literature 46: 285-332.

Lazer, David. 2005. "Regulatory Capitalism as a Networked Order." Annals of the American Academy of Political and Social Science 598: 52-66.

Lawrence, David P. 2007. "Impact Significance determination—Pushing the Boundaries.” Environmental Impact Assessment Review 27 (8): 770-88.

Levi-Faur, David. 2005. "The Global Diffusion of Regulatory Capitalism." Annals of the American Academy of Political and Social Science 598: 12-32.

Levi-Faur, David. 2011. "Regulation and Regulatory Governance." In Handbook on the Politics of Regulation, ed. David Levi-Faur, 3-21. Cheltenham: Edward Elgar.

Lindseth, Peter L., Alfred C. Aman Jr., and Alan C. Raul. 2008. Administrative Law of the European Union: Oversight, ed. George A. Bermann et al. Washington, D.C.: American Bar Association.

Livermore, Michael A. 2011. "Can Cost-Benefit Analysis of Environmental Policy Go Global?" New York University Environmental Law Journal 19: 146-93.

Livermore, Michael A., and Richard L. Revesz, eds. 2013. Cost-Benefit Analysis, Environmental Policy, and Emerging Economies. Oxford: Oxford University Press.

Losos, Jonathan B. 2011. "Convergence, Adaptation, and Constraint.” Evolution 65 (7): $1827-40$.

Lubbers, Jeffrey. 2012. A Guide to Federal Agency Rulemaking. $5^{\text {th }}$ edition, American Bar Association.

Macnaghten, Phil, and Michael Jacobs. 1997. "Public Identification with Sustainable Development: Investigating Cultural Barriers to Participation.” Global Environmental Change 7 (1): 5-24.

Mashaw, Jerry L., and David L. Harfst. 1990. The Struggle for Auto Safety. Harvard University Press.

McDermott, James E. 1979. "Improving NEPA: New Regulations of the Council on Environmental Quality." BC Envtl. Aff. L. Rev. 8: 89.

McGarity, Thomas O. 1992. "Some Thoughts on' Deossifying' the Rulemaking Process." Duke Law Journal, 1385-1462.

Melloni, Erica. 2013. "Ten Years of European Impact Assessment: How It Works, for What and for Whom." World Political Science Review 9 (1): 263-90.

Mendelson, Nina A. and Jonathan B. Wiener. 2014. "Responding to Agency Avoidance of OIRA." Harvard Journal of Law and Public Policy 37: 447-521.

Michaels, Ralf. 2009. "Comparative Law by Numbers? Legal Origins Thesis, Doing Business Reports, and the Silence of Traditional Comparative Law." American Journal of Comparative Law 57: 765-95.

Morrison-Saunders, Angus, and Thomas B. Fischer. 2006. "What Is Wrong with EIA and SEA Anyway? A Sceptic's Perspective on Sustainability Assessment.” Journal of Environmental Assessment Policy and Management 8 (1): 19-39. 
Wiener \& Ribeiro, Impact Assessment: Diffusion and Integration (DRAFT not for quotation - August

Morrison-Saunders, Angus, Jenny Pope, Jill A.E. Gunn, Alan Bond, and Francois Retief. 2014. "Strengthening Impact Assessment: A Call for Integration and Focus." Impact Assessment and Project Appraisal 32 (1): 2-8.

Mutombo, Emilie. 2012. 'Integrated Impact Assessment and 'The Environment': A New Research Perspective?” Quelle Transition Pour Nos Sociétés? 25.

Newig, Jens, and Oliver Fritsch. 2009. "Environmental Governance: Participatory, MultiLevel-and Effective?" Environmental Policy and Governance 19 (3): 197-214.

Organisation for Economic Co-operation and Development (OECD). 2008. Government Capacity to Assure High Quality Regulation in Brazil. Paris: OECD.

Organisation for Economic Co-operation and Development (OECD). 2009a. Regulatory Impact Analysis-Tool for Policy Coherence. Paris: OECD.

Organisation for Economic Co-operation and Development (OECD). 2009b. Part III: Profiles of the Western Balkan Countries and Kosovo under UNSCR 1244/99. Paris: OECD.

Organisation for Economic Co-operation and Development (OECD). 2011. Regulatory Management Indicators: Chile 2011. Paris: OECD.

Organisation for Economic Co-operation and Development (OECD). 2012a. Recommendation of the Council on Regulatory Policy and Governance (22 March), at http://www.oecd.org/document/33/0,3746,en_2649_34141_48081633_1_1_1_1,0 $\underline{0 . h t m l}$.

Organisation for Economic Co-operation and Development (OECD). 2012b. OECD Public Governance Reviews, Slovenia, Towards a Strategic and Efficient State, Paris: OECD.

Ovodenko, Alexander and Robert O. Keohane. 2012. "Institutional Diffusion in International Environmental Affairs.” International Affairs 88(3): 523-541.

Peci, Alketa and Felipe Sobral. 2011. "Regulatory Impact Assessment: How political and organizational forces influence its diffusion in a developing country." Regulation \& Governance 5: 204-220.

Pope, Jenny, David Annandale, and Angus Morrison-Saunders. 2004. "Conceptualising Sustainability Assessment.” Environmental Impact Assessment Review 24 (6): 595-616. doi:10.1016/j.eiar.2004.03.001.

Porter, Theodore M. 1996. Trust in Numbers. Princeton University Press.

Porter, Alan L., and John J. Fittipaldi. 1998. Environmental Methods Review: Retooling Impact Assessment for the New Century. Press Club. https://iaia.org/publicdocuments/specialpublications/Green\%20Book_Environmental\%20Methods\%20Review.pdf.

Porter, Alan L., and Frederick A. Rossini. 1983. "Why Integrated Impact Assessment.” In Integrated Impact Assessment. Boulder, Colo.: Westview Press.

Pope, Jenny, Alan Bond, Angus Morrison-Saunders, and Francois Retief. 2013. "Advancing the Theory and Practice of Impact Assessment: Setting the Research Agenda." Environmental Impact Assessment Review 41: 1-9.

Posner, Richard A. 2004. Catastrophe: Risk and Response. Oxford: Oxford University Press.

Priest, George L. 1977. "The Common Law Process and the Selection of Efficient Rules.” Journal of Legal Studies 6 (October): 65-82. 
Wiener \& Ribeiro, Impact Assessment: Diffusion and Integration (DRAFT not for quotation - August

Program for Enhancing Regulatory Quality (PERQ). 2011. RIA Compliance Manual. Hanoi: PERQ.

Quah, Euston, and Raymond Toh. 2012. Cost-Benefit Analysis: Cases and Materials. New York: Routledge.

Rachlinksi, Jeffrey J., and Cynthia R. Farina. 2002. "Cognitive Psychology and Optimal Government Design." Cornell Law Review 87: 549-615.

Radaelli, Claudio M. 2005. "Diffusion without Convergence: How Political Context Shapes the Adoption of Regulatory Impact Assessment." Journal of European Public Policy 12: 924-43.

Radaelli, Claudio M. 2010. "Rationality, Power, Management and Symbols: Four Images of Regulatory Impact Assessment." Scandinavian Political Studies 33 (2): 164.

Radaelli, Claudio M., and Fabrizio De Francesco. 2008. "Regulatory Impact Assessment." In The Oxford Handbook of Regulation, ed. Martin Cave, Robert Baldwin and Martin Lodge, Oxford: Oxford University Press).

Reimann, Mathias. 2001. "Beyond National Systems: A Comparative Law for the International Age." Tulane Law Review 75: 1103-19.

Renda, Andrea. 2006. Impact Assessment in the EU. Brussels: Center for European Policy Studies.

Renda, Andrea. 2011. Law and Economics in the RIA World. Intersentia Ltd., Cambridge UK.

Renda, Andrea, Lorna Schrefler, Giacomo Luchetta, and Roberto Zavatta. 2013. Assessing the Costs and Benefits of Regulation. CEPS. http://ec.europa.eu/smartregulation/impact/commission_guidelines/docs/131210_cba_study_sg_final.pdf .

Revesz, Richard L., and Michael A. Livermore. 2008. Retaking Rationality: How CostBenefit Analysis Can Better Protect the Environment and Our Health. Oxford: Oxford University Press.

Revesz, Richard L. and Michael A. Livermore. 2013. The Globalization of Cost-Benefit Analysis in Environmental Policy. New York: Oxford University Press.

Revesz, Richard L. and Michael A. Livermore. 2014. "Rethinking Health-Based Environmental Standards," NYU Law Review 89:

Roe, Mark J. 1996. "Chaos and Evolution in Law and Economics." Harvard Law Review 109: 641-71.

Roe, Mark J. 2006. "Legal Origins, Politics, and Modern Stock Markets." Harvard Law Review 120: 460-527.

Rogers, M. Everett. 2003. The Diffusion of Innovations. 5th ed. (1st ed. 1963). New York: Free Press.

Rose-Ackerman, Susan, and Peter Lindseth, eds. 2010. Comparative Administrative Law. Northampton, Mass.: Edward Elgar.

Rose, Richard. 1993. Lesson-Drawing in Public Policy. Chatham: Chatham House.

Rozema, Jaap G., Alan J. Bond, Matthew Cashmore, and Jason Chilvers. 2012. "An Investigation of Environmental and Sustainability Discourses Associated with the Substantive Purposes of Environmental Assessment." Environmental Impact Assessment Review 33 (1): 80-90.

Sadler, Barry. 1996. International Study of the Effectiveness of Environmental Assessment: Final Report: Environmental Assessment in a Changing World: Evaluating Practice to Improve Performance. 
Wiener \& Ribeiro, Impact Assessment: Diffusion and Integration (DRAFT not for quotation - August 2014) page 36

Sánchez, Luis E. 2006. Avaliação de Impacto Ambiental: Conceitos E Métodos.

Sand, Peter H. 1971. "Current Trends in African Legal Geography: The Interfusion of Legal Systems." African Legal Studies 5: 1-27.

Sand, Peter H. 2011. "Information Disclosure.” In The Reality of Precaution: Comparing Risk Regulation in the United States and Europe, ed. Jonathan B. Wiener, Michael D. Rogers, James K. Hammitt, and Peter H. Sand, 323-360. Washington, D.C.: RFF Press/Earthscan.

Schiffer, Lois J. 2004. "The National Environmental Policy Act Today, with an Emphasis on Its Application Across U.S. Borders." Duke Environmental Law and Policy Forum 14: 325-425.

Shapiro, Stuart, and John Morrall. 2013. "Does Haste Make Waste? How Long Does It Take to Do a Good Regulatory Impact Analysis?" Administration \& Society. http://aas.sagepub.com/content/early/2013/08/19/0095399713498745.abstract.

Schachter, Daniel L., Donna Rose Addis, and Randy L. Buckner. 2008. "Episodic Simulation of Future Events: Concepts, Data, and Applications." Annals of the New York Academy of Sciences 1124: 39-60.

Schuck, Peter. 2014. Why Government Fails So Often and How It Can Do Better. Princeton University Press.

Schwartz, Jason. 2010. 52 Experiments with Regulatory Review: The Political and Economic Inputs into State Rulemaking. NYU Institute for Policy Integrity, Report No. 6.

Seidenfeld, Mark B. 2002. "Cognitive Loafing, Social Conformity, and Judicial Review of Agency Rulemaking." Cornell Law Review 87: 486-548.

Sezen, Seriye. 2011. "International versus domestic explanations of administrative reforms: the case of Turkey." International Review of Administrative Sciences 77: 322-346.

Shapiro, Stuart. 2006. "Politics and Regulatory Policy Analysis." Regulation 29 (2): 4045.

Siems, Mathias M. 2007. "The End of Comparative Law." Journal of Comparative Law 2: $133-50$.

Simmons, Beth A., Frank Dobbin, and Geoffrey Garrett, eds. 2008. The Global Diffusion of Markets and Democracy. Cambridge: Cambridge University Press.

Slaughter, Anne-Marie. 2004. A New World Order. Princeton: Princeton University Press.

Slaughter, Anne-Marie. 2009. "The Networked Century." Foreign Affairs 88 (JanuaryFebruary): 94-113.

Slovic, Paul. 2007. "If I Look at the Mass I Will Never Act: Psychic Numbing and Genocide." Judgment and Decision Making 2 (2): 79-95.

Stern, Jessica and Jonathan B. Wiener. 2008. "Precaution Against Terrorism." In Paul Bracken, Ian Bremmer and David Gordon, eds., Managing Strategic Surprise: Lessons from Risk Assessment and Risk Management 110-183 (Cambridge University Press).

Stewart, Richard B. 1975. "The Reformation of American Administrative Law." Harvard Law Review 88: 1667. 
Wiener \& Ribeiro, Impact Assessment: Diffusion and Integration (DRAFT not for quotation - August 2014) page 37

Stewart, Richard B. 2014. "Remedying Disregard in Global Regulatory Governance: Accountability, Participation, and Responsiveness." American Journal of International Law 108, No. 2 (April): 211-270.

Stiglitz, Joseph. 1997. "Looking Out for the National Interest: The Principles of the Council of Economic Advisers." American Economic Review (Papers \& Proceedings), Vol. 87, No. 2 (May), pp.109-113.

Stone, Diane. 2012. "Transfer and Translation of Policy." Policy Studies 33(4): 1-17.

Suh, Sangwon, Manfred Lenzen, Graham J. Treloar, Hiroki Hondo, Arpad Horvath, Gjalt Huppes, Olivier Jolliet, Uwe Klann, Wolfram Krewitt, and Yuichi Moriguchi. 2004. "System Boundary Selection in Life-Cycle Inventories Using Hybrid Approaches." Environmental Science \& Technology 38 (3): 657-64.

Sunstein, Cass R. 2000. "Cognition and Cost-Benefit Analysis." Journal of Legal Studies 29: 1059- .

Sunstein, Cass R. 2007. Worst-Case Scenarios. Cambridge: Harvard University Press.

Sunstein, Cass R. 2013a. Simpler: The Future of Government. Simon \& Schuster.

Sunstein, Cass R. 2013b. "The Office of Information and Regulatory Affairs: Myths and Realities." Harvard Law Review 126: 1838-1878.

Sunstein, Cass R., and Timur Kuran. 1999. "Availability Cascades and Risk Regulation.” Stanford Law Review 51: 683-768.

Surowiecki, James. 2004. The Wisdom of Crowds: Why the Many Are Smarter Than the Few and How Collective Wisdom Shapes Business, Economies, Societies and Nations. New York: Doubleday.

Truen, Sarah. 2011. Regulatory Impact Assessment in SADC: Improving Regional Regulatory Outcomes. Los Angeles: AECOM International Development for USAID/Southern Africa.

Tushnet, Mark. 1999. "Possibilities of Comparative Constitutional Law." Yale Law Journal 108: 1225-1309.

United Nations Environment Programme (UNEP). 2005. Regulatory Impact Assessment and Cost-Benefit Analysis in Uganda. Nairobi: UNEP.

Vanclay, Frank. 2004. "The Triple Bottom Line and Impact Assessment: How Do TBL, EIA, SIA, SEA and EMS Relate to Each Other?" Journal of Environmental Assessment Policy and Management 6 (03): 265-88.

Viner, Jacob. 1949. "Bentham and J.S. Mill: The Utilitarian Background.” American Economic Review 39: 360-82.

Vogel, David. 1986. National Styles of Regulation: Environmental Policy in Great Britain and the United States. Ithaca: Cornell University Press.

Vogel, David. 2012. The Politics of Precaution: Regulating Health, Safety and Environmental Risks in the United States and Europe. Princeton: Princeton University Press.

Walker, Jack L. 1969. "The Diffusion of Innovation among the American States." American Political Science Review 63: 880-89.

Watson, Alan. 1993. Legal Transplants: An Approach to Comparative Law. 2nd ed. Athens: University of Georgia Press.

Weber, Elke U. 2006. "Experience-Based and Description-Based Perceptions of LongTerm Risk: Why Global Warming Does Not Scare Us (Yet)." Climatic Change 77: 103-120. 
Wiener \& Ribeiro, Impact Assessment: Diffusion and Integration (DRAFT not for quotation - August 2014) page 38

Weyland, Kurt. 2005. "Theories of Policy Diffusion.” World Politics 57: 262-95. Wiener, Jonathan B. 1997. "Risk in the Republic." Duke Envtl. L. \& Pol'y F. 8: 1. Wiener, Jonathan B. 1998. "Managing the Iatrogenic Risks of Risk Management." Risk: Health, Safety and Environment 9: 39-82.

Wiener, Jonathan B. 2001. "Something Borrowed for Something Blue: Legal Transplants and the Evolution of Global Environmental Law." Ecology Law Quarterly 27: 1295-1371.

Wiener, Jonathan B. 2002. "Precaution in a Multirisk World." In Human and Ecological Risk Assessment: Theory and Practice, ed. Dennis D. Paustenbach, 1509-31. New York: Wiley and Sons.

Wiener, Jonathan B. 2003. "Whose Precaution after All? A Comment on the Comparison and Evolution of Risk Regulatory Systems." Duke Journal of International and Comparative Law 13: 207-62.

Wiener, Jonathan B. 2005. "Reviews of Catastrophe by Richard Posner and Collapse by Jared Diamond." Journal of Policy Analysis and Management 24: 885-90.

Wiener, Jonathan B. 2006. "Better Regulation in Europe." Current Legal Problems 59: 447-518.

Wiener, Jonathan B. 2011. "The Real Pattern of Precaution." In The Reality of Precaution: Comparing Risk Regulation in the United States and Europe, ed. Jonathan B. Wiener, Michael D. Rogers, James K. Hammitt and Peter H. Sand, 519-565. Washington, D.C.: RFF Press/Earthscan.

Wiener, Jonathan B. 2013. "The Diffusion of Regulatory Oversight." In The Globalization of Cost-Benefit Analysis in Environmental Policy, eds. Michael A. Livermore and Richard L. Revesz, 123-141. New York: Oxford University Press.

Wiener, Jonathan B., and Alberto Alemanno. 2010. "Comparing Regulatory Oversight Bodies across the Atlantic: The Office of Information and Regulatory Affairs in the U.S. and the Impact Assessment Board in the EU." In Comparative Administrative Law, ed. Susan Rose-Ackerman and Peter Lindseth, 309-335. Northampton, Mass.: Edward Elgar.

Wiener, Jonathan B., and Alberto Alemanno. 2015. "Improving International Regulatory Cooperation: TTIP as a Step Toward a Global Policy Laboratory." Law \& Contemporary Problems 78: -- (forthcoming).

Wiener, Jonathan B., and Barak D. Richman. 2010. "Mechanism Choice.” In Research Handbook on Public Choice and Public Law, ed. Daniel Farber and Anne Joseph O’Connell, 363-396. Northampton, Mass.: Edward Elgar.

Wiener, Jonathan B., Michael D. Rogers, James K. Hammitt, and Peter H. Sand, eds. 2011. The Reality of Precaution: Comparing Risk Regulation in the United States and Europe. Washington, D.C.: RFF Press/Earthscan.

Wiener, Jonathan B., and John D. Graham. 1995. "Resolving Risk Tradeoffs." In Risk vs. Risk: Tradeoffs in Protecting Health and the Environment, eds. John D. Graham \& Jonathan B. Wiener, 226-271. Cambridge: Harvard University Press. Wildavsky, Aaron. 1979.“ No Risk is the Highest Risk of All.” American Scientist 67: 32-37.

World Bank Group, Investment Climate Advisory Services. 2010. Better Regulation for Growth: Institutions for Regulatory Governance. Washington, D.C.: World Bank. 
Wiener \& Ribeiro, Impact Assessment: Diffusion and Integration (DRAFT not for quotation - August 2014) page 39

Zweigert, Konrad, and Hein Kotz. 1998. An Introduction to Comparative Law. 3rd ed. Trans. Tony Weir. Oxford: Oxford University Press. 